\title{
Conservation status of the American horseshoe crab, (Limulus polyphemus): a regional assessment
}

\author{
David R. Smith ${ }^{(1)}$ - H. Jane Brockmann • Mark A. Beekey • \\ Timothy L. King • Michael J. Millard · Jaime Zaldívar-Rae
}

Received: 4 March 2016/Accepted: 24 November 2016/Published online: 10 December 2016

(C) The Author(s) 2016. This article is published with open access at Springerlink.com

\begin{abstract}
Horseshoe crabs have persisted for more than 200 million years, and fossil forms date to 450 million years ago. The American horseshoe crab (Limulus polyphemus), one of four extant horseshoe crab species, is found along the Atlantic coastline of North America ranging from Alabama to Maine, USA with another distinct population on the coasts of Campeche, Yucatán and Quintana Roo in the Yucatán Peninsula, México. Although the American horseshoe crab tolerates broad environmental conditions, exploitation and habitat loss threaten the species. We assessed the conservation status of the American horseshoe crab by comprehensively reviewing
\end{abstract}

\footnotetext{
This paper is dedicated to the memory of Timothy L. King (1958-2016), our friend and colleague whose research provided the foundation for understanding and guiding the conservation of many threatened and endangered species. We celebrate every aspect of Tim's life, which was impressive, and we are honored to have worked with him.
}

D. R. Smith $(\bowtie) \cdot$ T. L. King

U.S. Geological Survey, Leetown Science Center,

Kearneysville, WV, USA

e-mail: drsmith@usgs.gov

H. JaneBrockmann

Department of Biology, University of Florida,

Gainesville, FL, USA

\section{A. Beekey}

Department of Biological Sciences, Sacred Heart

University, Fairfield, CT, USA available scientific information on its range, life history, genetic structure, population trends and analyses, major threats, and conservation. We structured the status assessment by six genetically-informed regions and accounted for sub-regional differences in environmental conditions, threats, and management. The transnational regions are Gulf of Maine (USA), Mid-Atlantic (USA), Southeast (USA), Florida Atlantic (USA), Northeast Gulf of México (USA), and Yucatán Peninsula (México). Our conclusion is that the American horseshoe crab species is vulnerable to local extirpation and that the degree and extent of risk vary among and within the regions. The risk is elevated in the Gulf of Maine region due to limited and fragmented habitat. The populations of horseshoe crabs in the Mid-Atlantic region are stable in the Delaware Bay area, and regulatory controls are in place, but the risk is elevated in the New England area as evidenced by continuing declines understood to be caused by over-harvest. The populations of horseshoe

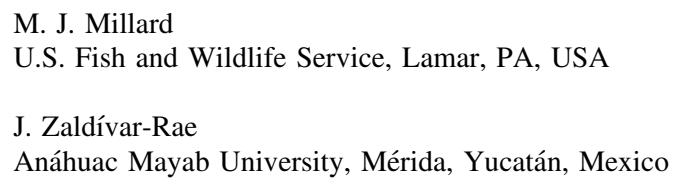


crabs in the Southeast region are stable or increasing. The populations of horseshoe crabs in the Florida Atlantic region show mixed trends among areas, and continuing population reductions at the embayment level have poorly understood causes. Within the Northeast Gulf of Mexico, causes of population trends are poorly understood and currently there is no active management of horseshoe crabs. Horseshoe crabs within México have conservation protection based on limited and fragmented habitat and geographic isolation from other regions, but elevated risk applies to the horseshoe crabs in the Yucatán Peninsula region until sufficient data can confirm population stability. Future species status throughout its range will depend on the effectiveness of conservation to mitigate habitat loss and manage for sustainable harvest among and within regions.

Keywords Limulus polyphemus $\cdot$ Species status assessment · Horseshoe crab - Limulus amebocyte lysate $\cdot$ Xiphosurida $\cdot$ Living fossil

\section{Introduction}

Horseshoe crabs have persisted for more than 200 million years (Shuster 1958; Botton and Ropes 1987; Shuster 2001; Tanacredi 2001; Shuster et al. 2003; Anderson and Shuster 2003; Błażejowski 2015), and distinct fossil forms of horseshoe crabs have been dated as far back as 450 million years ago (Sekiguchi 1988; Rudkin and Young 2009). Since the late nineteenth century, horseshoe crabs have been classified in the phylum Arthropoda allied with arachnids, and not with Crustacea as in earlier classifications (Sekiguchi 1988). All four extant species are in the Class Merostomata (Dana, 1852), Order Xiphosurida (Latreille, 1802), and Family Limulidae (Leach, 1819) (Sekiguchi 1988). The American horseshoe crab, Limulus polyphemus (Linnaeus, 1758) is the sole extant representative in the genus Limulus and inhabits the Atlantic coastline of North America ranging from the Yucatán Peninsula, México $\left(18^{\circ} \mathrm{N}\right)$ to Maine, USA $\left(42^{\circ} \mathrm{N}\right)$ (Fig. 1). The three remaining species, Tachypleus tridentatus (Leach, 1819), T. gigas (Müller, 1785), and Carcinoscorpius rotundicauda (Latreille, 1802), inhabit the coastal waters of Asia from India to Japan, including the East Indies and Philippines.
The conservation status of horseshoe crabs reflects extinction risk influenced by exploitation and habitat conditions, which vary by geography (Fig. 2). Horseshoe crabs have been harvested historically for use as fertilizer or bait, and more recently for extraction of blood for use in biopharmaceuticals (Berkson and Shuster 1999; Shuster 2003; Levin et al. 2003; Smith et al. 2009b). Although harvest records extend into the nineteenth century (Shuster 2003), management plans that regulate harvest are recent and may not adequately address the exploitation for the bait fishery, biomedical harvest, or locally intense marine-life harvest throughout the species range (ASMFC 1998; Millard et al. 2015). Coastal change, particularly from hardened shorelines and erosion, has resulted in a loss of suitable habitat (Botton et al. 1988; Hapke et al. 2013; Jackson et al. 2015), which will be affected by sea level rise (Loveland and Botton 2015). The geographic variation in the conservation status of the American horseshoe crab and the potential impact of emerging threats have not been comprehensively reviewed and assessed.

In this paper, the goal is to review the relevant biology and assess the conservation status of the American horseshoe crab. Conceptually, the status assessment integrates information on management and conservation actions, significant threats defined by sources and stressors, habitat, and populations (Fig. 2). The assessment is conducted within a regional framework provided by the species' population genetic structure (King et al. 2015). The population responses, abundance, geographic range, and viability, along with genetic structure inform risk at the regional level, which in turn, informs the assessment of a species extinction risk.

\section{Geographic range}

Horseshoe crabs occur along the Atlantic coast of North American from the Gulf of Maine to Florida and the coast of the Gulf of México from Florida to the Yucatán Peninsula (Fig. 1). They are absent, however, from the western and southern Gulf of Mexico from Texas, USA to Tabasco, México.

The distribution of horseshoe crabs extends to the north along the mid-Atlantic and northeastern states. Recent efforts to locate breeding populations (Schaller 2002; Schaller et al. 2005) reveal that the current 
Fig. 1 Range map for the American horseshoe crab (Limulus polyphemus), including geneticallyinformed regions used in the Red List assessment. Shading is included to contrast adjacent regions and indicate their geographic extent

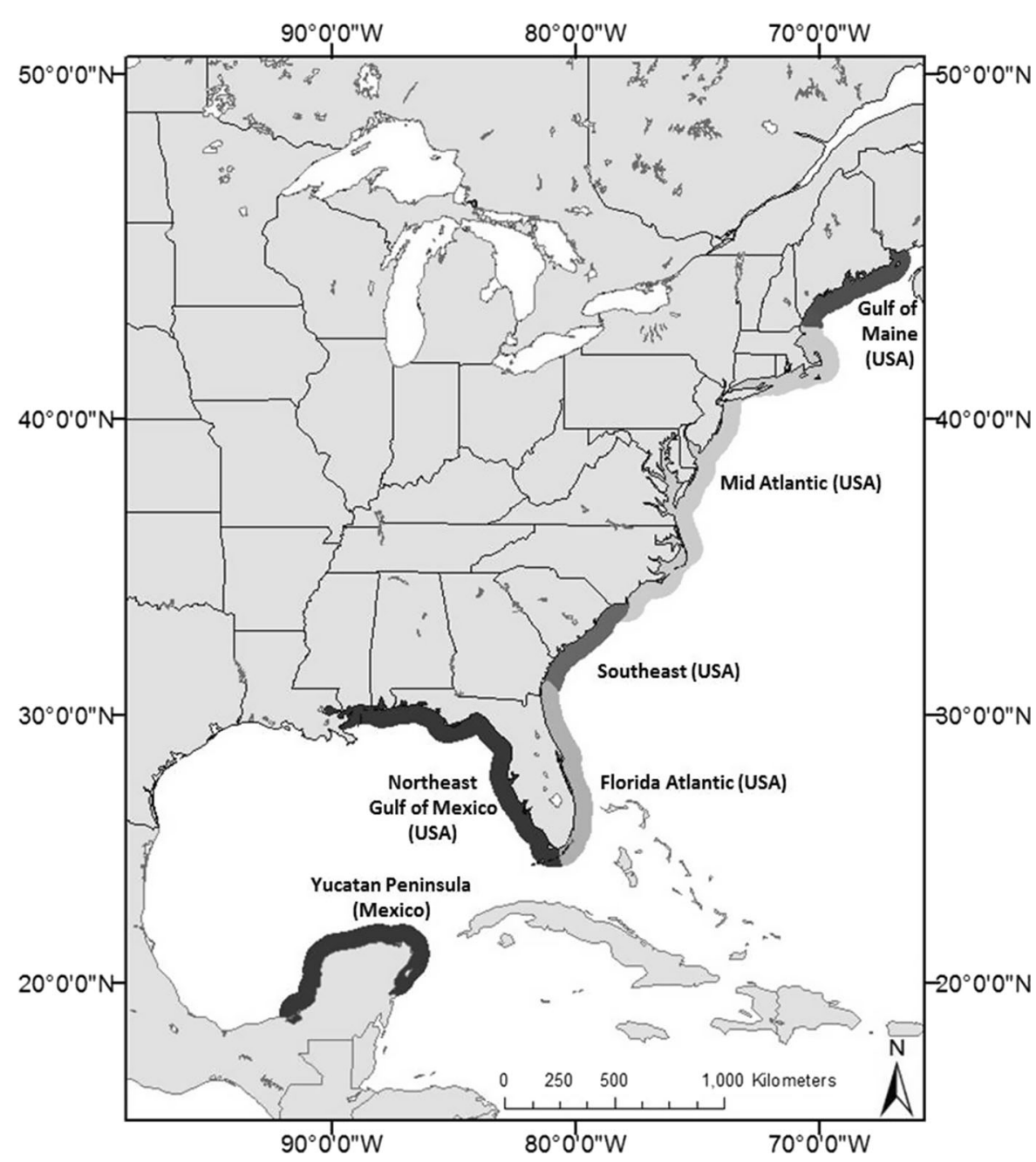

islands, from Cumberland to Tybee Island (Sandifer et al. 1980; D. Saunders, University of Georgia Marine Laboratory at Skidaway Island, and Jane Brockmann, University of Florida, personal communication). Horseshoe crabs also nest in all coastal counties along the east coast of Florida and on the Florida sea islands including Amelia Island, but they appear to be less common along the northeast coast of Florida (Florida Fish and Wildlife Conservation Commission on-line survey data; Gerhart 2007) than elsewhere in the state (Brockmann et al. 2015). Horseshoe crabs occur in the inlets (e.g. Ponce, Sabastian), lagoons (e.g. Mosquito), rivers (e.g. Halifax, Banana, Indian), and associated islands along the Southeast coast of Florida from Ponce Inlet to Jupiter, collectively referred to as the Indian River lagoon system (Ehlinger and Tankersley 2009). Much of this area is unusual habitat for 
Fig. 2 Conceptual model for the American horseshoe crab assessment showing influence of stressors, sources, and actions on population extinction risk. Climate change and socioeconomic factors are large-scale drivers that broadly affect actions, sources, and stressors. The acronym BMP stands for best management practice

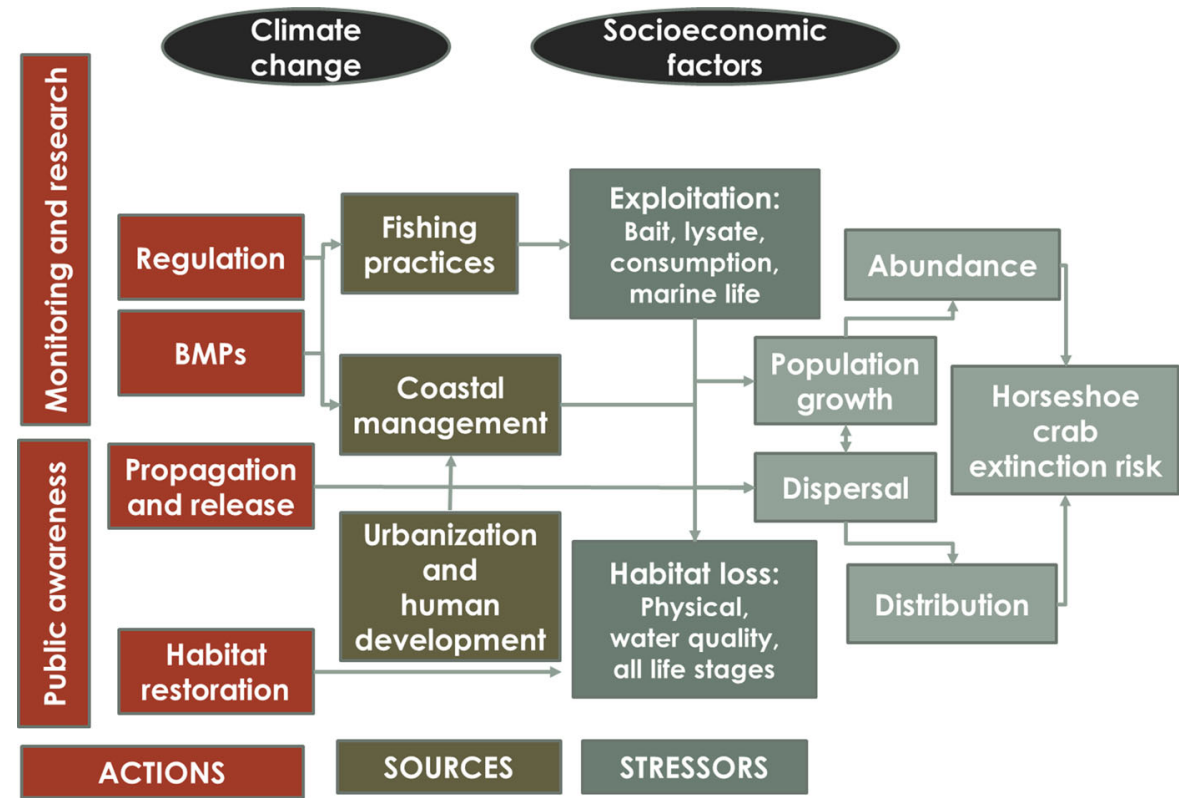

horseshoe crabs in that it is micro-tidal (Ehlinger et al. 2003).

Horseshoe crabs breed in all coastal counties along the west coast of Florida (Brockmann et al. 2015) including the Panhandle of Florida, the Florida Keys, and the Marquesas (Mikkelsen 1988), but there are no records as far west as the Dry Tortugas (Tracy Ziegler, Fisheries Biologist, Everglades and Dry Tortugas National Parks, personal communication). Florida FIM trawl surveys in the Gulf of Mexico have recorded horseshoe crabs in every month of the year (Brockmann et al. 2015). Farther west, horseshoe crabs are more rare along the coasts of Alabama and Mississippi compared to Florida; only three horseshoe crabs have been captured in Mississippi state trawl surveys since 1995 (Darcie Graham, University of Southern Mississippi Assistant Director, Center for Fisheries Research and Development, personal communication). However, horseshoe crabs are regularly seen breeding on the northern side of the Alabama barrier islands, on the Fort Morgan Peninsula and in the Gulf Shores area (Estes 2015), and west of Mobile Bay at Dauphin Island, Alabama (Hedgpeth 1954; Richmond 1962; Ruth Carmichael, Dauphin Island Sea Lab, personal communication), with breeding pairs rarely observed on the Fort Morgan Peninsula and Gulf Shores area of Alabama (Estes 2015), and occasional solitary individuals are found on the southern side of the barrier islands in Alabama and
Mississippi (Ruth Carmichael, Dauphin Island Sea Lab, personal communication). Horseshoe crabs also breed on Mississippi's Petit Bois Island (Ruth Carmichael, Dauphin Island Sea Lab, personal communication; Estes et al. 2015), Horn Island (Steve J. VanderKooy, Gulf States Marine Fisheries Commission, personal communication) and West Ship Island (Fulford and Haehn 2012). The western extent of historically recorded horseshoe crab breeding in the Gulf of México is the Chandeleur Islands, the easternmost barrier islands of Louisiana (Cary 1906). Louisiana has no records of horseshoe crabs in their trawl surveys (Martin Bourgeois, Louisiana Department of Wildlife and Fisheries, personal communication). There are no records of horseshoe crabs from the Texas trawl surveys (Glen Sutton, Texas Parks and Wildlife Department, personal communication), and only one historical record of a horseshoe crab collected at Padre Island in 1940-1941 (Hedgpeth 1954).

Along the Mexican coast of the Gulf of México and Caribbean Sea, horseshoe crabs occur on the Yucatán peninsula, i.e. in the states of Campeche, Yucatán and Quintana Roo (Britton and Morton 1989), with only rare reports of horseshoe crabs from Veracruz (Chávez and Muñoz-Padilla 1975) and no reports from the coasts of Tabasco or Tamaulipas. Breeding pairs are commonly seen on the west coast of the Yucatán Peninsula from Laguna de Términos and Isla del 
Carmen (southern Campeche) north to the mouths of the Champotón and Icahao rivers, the Petenes region (central and north Campeche) and Celestún (Yucatán), as well as along the north coast of the peninsula (Yucatán and the north coast of Quintana Roo, including the coastal lagoon systems of Sisal, Chuburná, Progreso-Yucalpetén, Laguna Rosada, Chabihau, Bocas de Dzilam, Ría Lagartos, Yalahau, and Chacmochuc; Jaime Zaldívar-Rae, Anáhuac Mayab University, personal communication). There are reports of horseshoe crabs on the east (Caribbean) coast of the peninsula (mainly in the Nichupté Coastal Lagoon System) and south at least to Tulum (Ives 1891; Gómez-Aguirre 1979) and Punta Allen (René Sapién, Universidad Nacional Autónoma de México, personal communication), on the northern limit of Bahia de la Ascension in Quintana Roo (Zaldívar-Rae et al. 2009). Horseshoe crabs in México are primarily associated with the mangrove communities in coastal lagoons and estuaries, but they migrate back and forth from the continental shelf (Jaime Zaldívar-Rae, Anáhuac Mayab Univerity, personal communication).

Although there are no published accounts of horseshoe crabs anywhere in the Caribbean, Mikkelsen (1988) reported that "Old books on the fauna of the West Indies describe horseshoe crabs on the coast of Jamaica." A few horseshoe crabs have been observed across some years in the Bahamas by Dr. Kathleen Sullivan-Seeley (Department of Biology, University of Miami, personal communication), who conducted invertebrate surveys in this area. Her logs (1986-2002) record the presence of horseshoe crabs at Chub Cay and Normans Cay on Shroud, Bogue Sound on South Caicos, Elizabeth Harbor on Exuma, and also on the islands of New Providence, and Eleuthera (unpublished data, Sullivan-Seeley, University of Miami, Bahamas log). She has not observed horseshoe crabs in Jamaica or on the southeast coast of the Dominican Republic, where she has conducted surveys over the course of 6 years with dives and trawls. Scientists in Cuba report that they have not seen breeding horseshoe crabs in Cuba (Erick Perera, Center for Marine Research in Havana, personal communication), although individual animals may be found there occasionally.

The distribution of horseshoe crabs does not appear to have been influenced by transport and introduction into new areas. There are some old accounts of horseshoe crabs sightings in Europe (e.g. Southwell
1873; Lloyd 1874), and from 1968 to 1976, at least eighteen were collected by fishermen or found on northern European beaches and the presumption is that humans transported these animals across the Atlantic (Wolff 1977). Reports of Limulus in waters along Israel and western Africa were probably also due to transplanted animals (Mikkelsen 1988; Anderson and Shuster 2003). A small population was introduced into Galveston Bay, Texas (Britton and Morton 1989), but this population has not persisted (Dr. Paul Montagna, University of Texas, personal communication). Two previous large-scale introductions of Limulus, one into San Francisco Bay on the Pacific coast of the United States (MacGinitie and MacGinitie 1949) and the other along the southern coast of the North Sea (Lloyd 1874), did not result in the permanent establishment of the species in either location (Wolff 1977).

\section{Population genetic structure}

Due to their morphological similarity to mid-Mesozoic taxa, horseshoe crabs are considered to be evolutionarily static (Kin and Błażejowski 2014) and have been referred to as phylogenetic relics (Selander et al. 1970). However, close inspection has revealed the presence of considerable morphological and genetic variability (Shuster 1979; Riska 1981; Selander et al. 1970; King et al. 2005; Faurby et al. 2010). A range of molecular genetic techniques applied across multiple studies has been utilized in attempts to assess population structure (stock identification) in horseshoe crabs. These studies, which now include the first range-wide surveys of nuclear DNA variation in any horseshoe crab (King et al. 2015), do not support the null hypothesis of a homogeneous gene pool for horseshoe crabs inhabiting the Atlantic coast of North America. Rather, the pattern of genetic variation (King et al. 2015) observed is consistent with that identified previously in surveys of morphological variation (Shuster 1979; Riska 1981).

A survey of allozyme variation among four broadly distributed collections suggested that Atlantic and Gulf of México populations of horseshoe crabs were genetically differentiated (Selander et al. 1970). A subsequent study of mitochondrial DNA (mtDNA) variation identified a major genetic discontinuity that distinguished northern from southern populations with a phylogeographic break occurring around Cape 
Canaveral, along Florida's Atlantic coast (Saunders et al. 1986). At a finer scale, Pierce et al. (2000) reported little evidence of gene flow between Delaware and Chesapeake Bay horseshoe crab populations as reflected by sequence variation in the mtDNA cytochrome oxidase subunit I region, although variation at randomly amplified polymorphic DNA (RAPD) markers was uniform, implying that gene flow may be sex-biased. Microsatellite analysis of horseshoe crabs in Long Island Sound revealed that the population is comparable to other Mid-Atlantic populations of horseshoe crabs. The number of effective alleles and heterozygosity of the populations are not significantly different from published data of populations in the Greater Delaware Bay Region (Kasinak et al. 2011). More recently, King et al. (2005, 2015) surveyed neutral (assumed) genetic variation at 13 microsatellite DNA markers among 1841 horseshoe crabs sampled at 35 spawning locations (Table 1) from northern Maine to the Yucatán Peninsula, México. This extensive intraspecific examination of the nuclear genome (nDNA) revealed considerable allelic diversity and differentiation (population structuring).

These recent findings (King et al. 2005, 2015) suggest the presence of similar levels of genetic diversity and variation among the collections, punctuated with a series of genetic discontinuities of varying "depth" across the species' range that could indicate demographic independence, regional adaptation, and reflect vicariant geographic events. Populations sampled within these regional groupings exhibit shallow but statistically significant differentiation. Moreover, populations at the ends of the range are more differentiated from nearby populations than are populations in the middle of the range from their neighbors. Faurby et al. (2010) used Bayesian coalescent-based methods to the neutral microsatellite data and concluded that extremes of the range are differentiated most likely due to climate change associated with the "Little Ice Age".

Patterns of genotypic variation in the nDNA at the individual and population scales suggest three major zones of genetic discontinuity: (1) the Southeast (and northward) from the Florida Atlantic [Florida Indian River (FIR) and Biscayne Bay (FBB)] collections; (2) the Florida Atlantic (to the southern tip of Florida) from the Florida Gulf of México collections; and (3) the Florida Gulf of México from the Yucatán, México collections (Figs. 1, 3; Table 1). The latter discontinuity was identified using collections from a single locality on the northeast coast of the Yucatán Peninsula (San Felipe-Río Lagartos); hence, there may be other zones of genetic discontinuity within the Mexican part of the distribution. Narrower zones of genetic discontinuity were evident between: (a) the Gulf of Maine and Mid-Atlantic collections, (b) the MidAtlantic and Southeast collections (SC and GA), and (c) the Tampa Bay and Cedar Key collections. An additional zone of discontinuity may exist between Alligator Point and St. Joseph Bay along the Florida panhandle. The relatively small sample size from St. Joseph Bay precludes a determination at this time. This phylogeographic pattern implies there are at least seven demographically distinct lineages across the species' range that are relevant to conservation. These data also suggest low levels of gene exchange between collections on either side of these genetic discontinuities. Additional data across the Gulf of Mexico may further divide or unify the population structure of this region.

In addition to the demographically discrete lineages (based on high regional $\mathrm{F}_{\mathrm{ST}}$ values and low gene flow) delineated by zones of genetic discontinuity identified for horseshoe crabs (King et al. 2015), a series of metapopulations and other individual collections delineated within each discrete lineage may be considered distinct management/recovery units for future management planning purposes. Metapopulations may exist in the Gulf of Maine (Maine and New Hampshire collections), the entire Mid-Atlantic region (with some substructure within), the upper Chesapeake Bay collections (MDT, MDF), the Southeast assemblage (SBB, SBE, GSA, and GSI), southwest Florida Gulf of México (FMI, FCH, FTB), and the northwest Florida Gulf of México (FCK, FAP). Within areas bounded by zones of genetic discontinuity, there appears to be substantial gene flow between each population and its nearest neighbors.

The high genetic diversity of these populations revealed through mitochondrial and nuclear DNA markers allows assessment of sex-specific gene flow patterns, which indicate decreased female vagility (ability to move) and increased male vagility, which peaks in the region between the Chesapeake and Delaware Bays. There is significantly more male migration between these two bays than female gene flow (King et al. 2005). This sex-biased dispersal 
Table 1 Abbreviation, general location, and sample size for 35 spawning and 5 near- or off-shore dredge or trawl collections of horseshoe crabs Limulus polyphemus genotyped at 13 microsatellite DNA loci to assess population structuring

\begin{tabular}{|c|c|c|}
\hline Abbreviation & Spawning collection site & Sample size \\
\hline $\mathrm{MEH}$ & Hog Bay, Franklin, Maine & 47 \\
\hline MET & Thomas Point Beach, Maine & 45 \\
\hline MEM & Middle Bay, Brunswick, Maine & 48 \\
\hline NHS & Chadman's Landing, Squamscott River, New Hampshire & 48 \\
\hline MAP & Pleasant Bay, Massachusetts & 48 \\
\hline RIN & Green Island, Narragansett Bay, Rhode Island & 48 \\
\hline CTH & Housatonic River, Milford Point, Connecticut & 48 \\
\hline NYP & Great Peconic Bay, Long Island, New York & 48 \\
\hline NJF & Fortescue Beach, New Jersey & 48 \\
\hline NJR & Reeds Beach, New Jersey & 48 \\
\hline NJH & Highs Beach, New Jersey & 49 \\
\hline DKH & Kitt's Hummock Beach, Delaware & 36 \\
\hline DBS & Big Stone Beach, Delaware & 31 \\
\hline DFB & Fowler Beach, Delaware & 47 \\
\hline MDT & Turkey Point, Chesapeake Bay, Maryland & 30 \\
\hline MDF & Flag Pond State Park, Chesapeake Bay, Maryland & 29 \\
\hline MD5 & Ocean City, Maryland-2005 & 48 \\
\hline MD6 & Ocean City, Maryland-2006 & 48 \\
\hline VAC & Chincoteague, Virginia & 48 \\
\hline VKI & Kiptopeke St. Park, Chesapeake Bay, Virginia & 48 \\
\hline VAI & Tom's Cove, Assateague Island, Virginia & 48 \\
\hline NCS & Shackleford Banks, North Carolina & 55 \\
\hline SBB & Bulls Bay, South Carolina & 53 \\
\hline SBE & Beaufort, South Carolina & 48 \\
\hline GSA & Savannah, Georgia & 48 \\
\hline GSI & Sapelo Island, Georgia & 32 \\
\hline FIR & Indian River, Florida (Atlantic coast) & 47 \\
\hline FBB & Biscayne Bay & 20 \\
\hline FMI & Tiger Tail Beach, Marco Island, Florida (Gulf coast) & 81 \\
\hline $\mathrm{FCH}$ & Charlotte Harbor, Florida & 51 \\
\hline FTB & Tampa Bay, Florida & 201 \\
\hline FCK & Seahorse Key, Cedar Keys NWR, Florida & 132 \\
\hline FAP & Alligator Point, Apalachicola Bay, Florida & 92 \\
\hline FSJ & St. Joseph Bay, Florida & 23 \\
\hline \multirow[t]{2}{*}{ MXY } & Ria Lagartos and San Felipe, Yucatán, Republic of México & 20 \\
\hline & Subtotal & 1841 \\
\hline \multicolumn{3}{|c|}{ Near- or off-shore dredge or trawling collection } \\
\hline NYL & Offshore Long Island, New York (trawl) & 46 \\
\hline NJC & Offshore Cape May Canal Inlet, New Jersey (trawl) & 48 \\
\hline MOC & Ocean City, Maryland (trawl) & 48 \\
\hline $\mathrm{VCH}$ & Chincoteague Island (commercial dredge) & 46 \\
\hline \multirow[t]{3}{*}{ FWS } & US Fish and Wildlife Service Cruise 2007 (trawl) & 48 \\
\hline & Subtotal & 236 \\
\hline & Total & 2077 \\
\hline
\end{tabular}


Fig. 3 Neighbor-joining phenogram depicting genetic distance (chord, Cavalli-Sforza and Edwards 1967) among 35 Limulus polyphemus collections sampled from the Atlantic and Gulf coasts of the United States and Ria Lagartos and San Felipe, Yucatán, Republic of México (King et al. 2015). Brackets group collections into suggested management units. Abbreviations for spawning site collections are found in Table 1

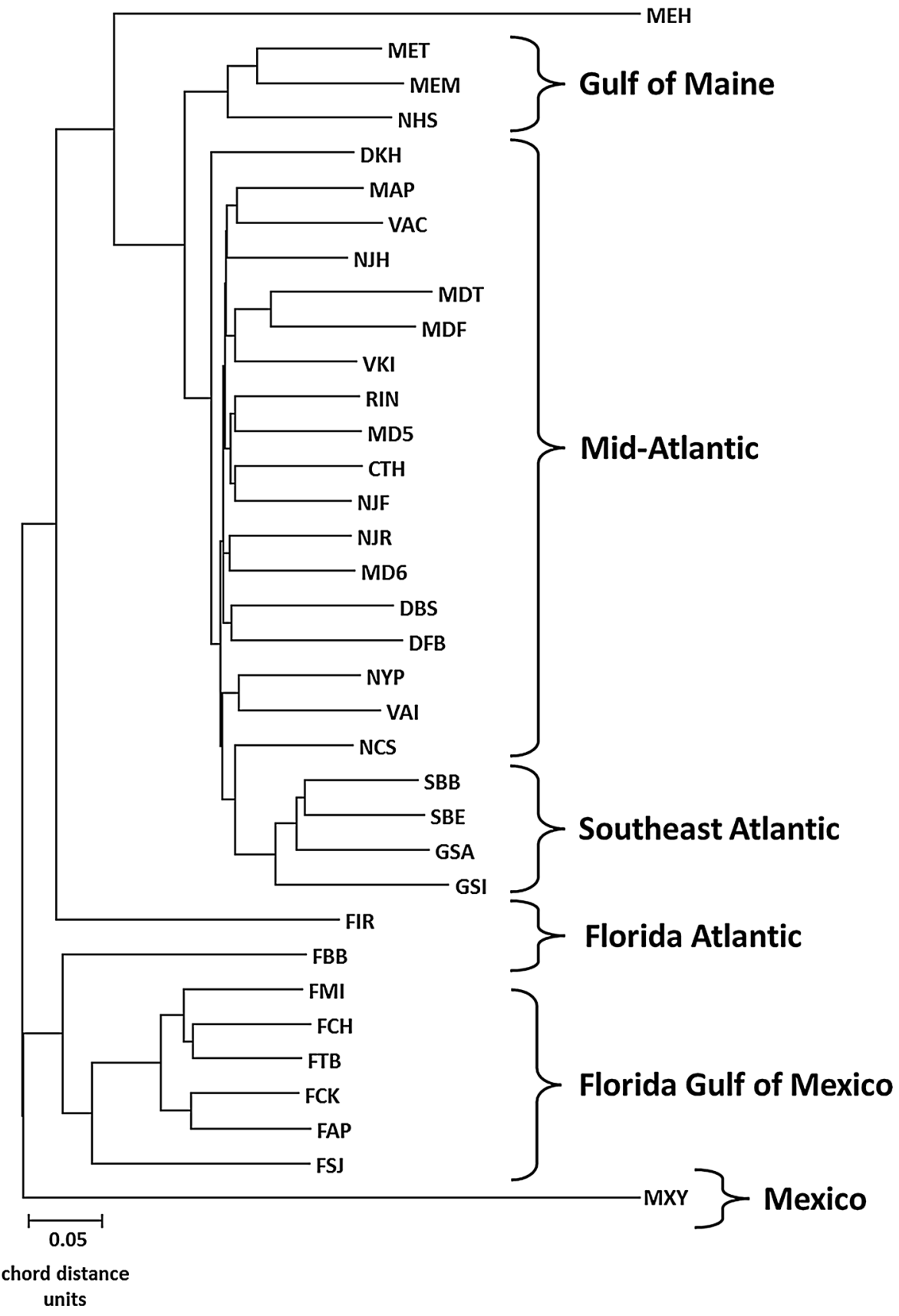

implies that should a population become extirpated, gene flow alone may not be sufficient to repopulate an area due to limited larval dispersal potential (Botton and Loveland 2003) and female migration (Swan 2005) between embayments (King et al. 2005).

Any further quantification of the degree of migration between Delaware and Chesapeake Bays is difficult due the absence of genetic structure between sample collections from the two bays. Additional mitochondrial DNA data validated by tagging studies targeting females are required to allow quantification of the effective migration between Chesapeake and Delaware Bays. Shuster (Shuster 1985) hypothesized an overlap in distribution between the populations within the Chesapeake and Delaware Bays, but notes that Chesapeake Bay crabs are smaller than Delaware 
Bay crabs. Swan (2005) found that among the 14 horseshoe crabs that were tagged in DE Bay and observed to have traveled $>100 \mathrm{~km}$, one was recovered in the Chesapeake Bay, but not during spawning season.

In their entirety, these research findings suggest a series of discontinuities across the species' range that could indicate regional adaptive significance or reflect vicariant geographic events. Regional groupings (Fig. 3) may warrant management-unit status (Palsbøll et al. 2007) based on the presence of statistically significant allele frequency heterogeneity, allocation of genetic diversity, and a high percentage of correct classification for region of origin. Moreover, a pattern of male-biased gene flow was observed among all collections from Maine to Florida's eastern Gulf of Mexico coast that suggests that management efforts might best be targeted at this finer scale (Fig. 3). These findings also provide justification for release of horseshoe crabs sampled by scientific or commercial interests near the original collection site. The integration of the information from the nuclear genome with previously identified allozyme (Selander et al. 1970) and mitochondrial DNA variation (Saunders et al. 1986; Pierce et al. 2000) and ecological data should prove essential to developing an ecologically and evolutionarily sound management strategy (Moritz 1994).

Based on the major zones of discontinuity in the genotypic patterns of nDNA, we structured the risk assessment into the following regions and then integrated the regional assessments to the species level. The transnational genetically-informed regions were (Figs. 1, 3):

- Gulf of Maine (USA), including embayments from Great Bay estuary in New Hampshire and north into Maine.

- Mid-Atlantic (USA), including all embayments south of New Hampshire to and including North Carolina.

- Southeast (USA), including embayments in South Carolina and Georgia, but note that the Georgia population extends into northern Florida.

- Florida Atlantic (USA), including embayments along the Atlantic coast of Florida south of the Georgia population.

- Northeast Gulf of Mexico (USA), including embayments along the Gulf coast of Florida,
Alabama, barrier islands of Mississippi, and easternmost barrier island of Louisiana.

- Yucatán Peninsula (México), including embayments on the western, northern, and eastern portions of the peninsula (the Mexican states of Campeche, Yucatán, and Quintana Roo) and Mexican portion of the Caribbean Sea.

The regional boundaries are intended to account for the genetic structure at a scale relevant to conservation and management. The small samples from areas within the Northeast Gulf and Yucatán Peninsula (Table 1) limit the inference about population genetic structure. Because population connectivity and threats vary within and among regions, we assess regional conservation status for each region, while noting substantial variation of ecology, threats, and management.

\section{Life history, ecology and habitat}

Horseshoe crab ecology varies across the species' range. Given this geographic variation, this section generalizes the species' life history characteristics, ecological role, and habitat requirements relevant to understanding their conservation and status.

Reproduction

\section{Spawning}

The timing of spawning varies with latitude. Increased water temperatures in the spring stimulate adult horseshoe crabs to migrate from deeper waters where they overwinter toward shallow waters where they spawn (Shuster 1982; Watson et al. 2009; Table 2). At the northern end of their range, horseshoe crabs breed in May and June, moving up the estuaries in which they overwinter as the water warms (Cheng et al. 2015; Moore and Perrin 2007; Schaller et al. 2010). In Cape Cod, Massachusetts, spawning occurs from May through July with peaks in May and June (Barlow et al. 1986; Widener and Barlow 1999; James-Pirri et al. 2005). In Long Island Sound, spawning begins in early May and peaks by the end of May (Beekey and Mattei 2009). In Delaware Bay, spawning occurs from April through at least July, with peak spawning in May and June (Shuster and Botton 1985; Michels et al. 2008; 


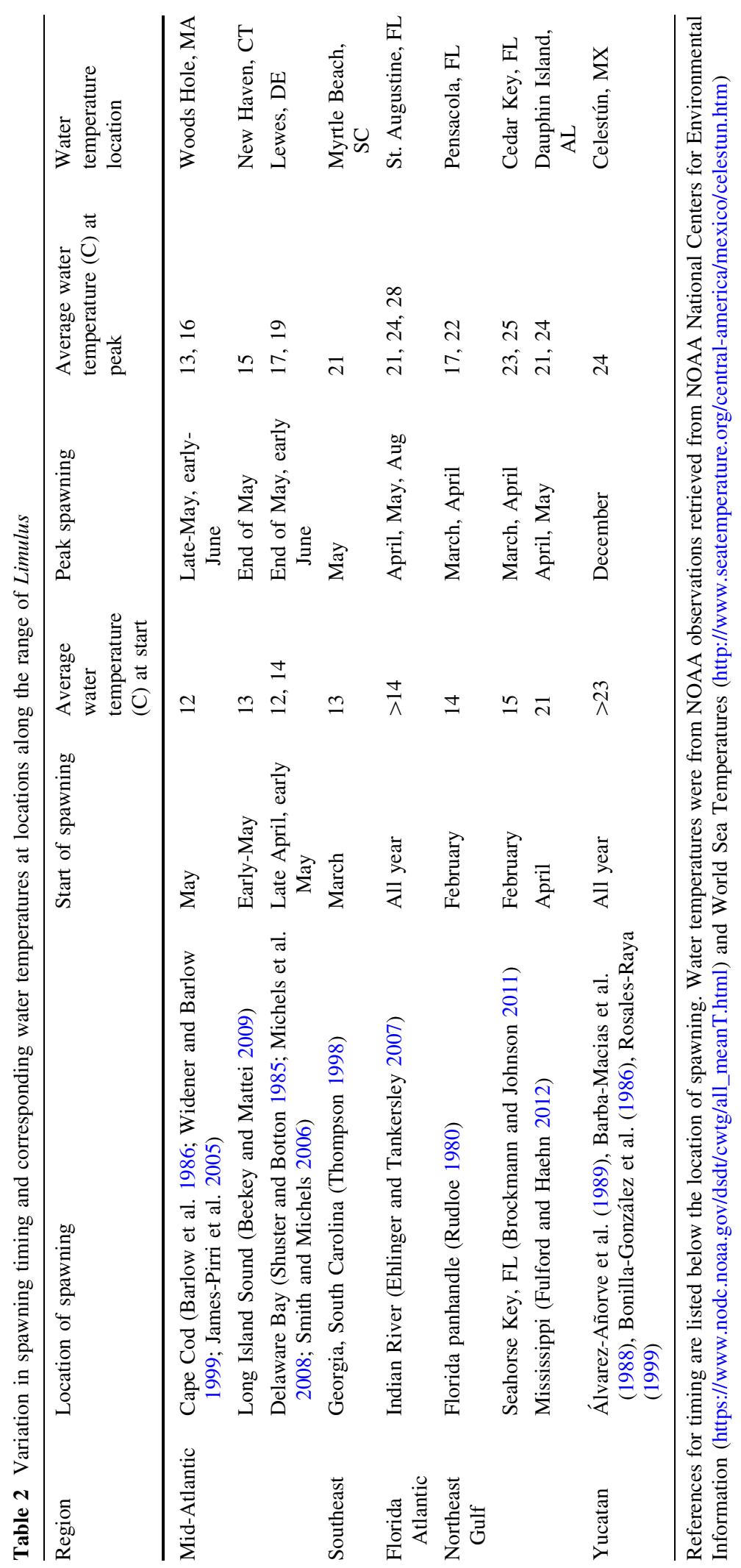


Smith and Michels 2006). In Georgia and South Carolina, spawning has been reported from March to July, peaking in May (Thompson 1998). In South Florida (FWC on-line survey) and Indian River Lagoon area of Florida (Ehlinger and Tankersley 2007), horseshoe crabs have been observed spawning during every month of the year with peaks in April, May and August. Along the west coast of the Florida and Gulf coast, breeding is most common from February through October with peaks in March and April (Rudloe 1980; Brockmann et al. 2015; FWC online survey). In Mississippi, spawning is observed from early April to mid-November with a peak in April and May (Fulford and Haehn 2012). In the Yucatán spawning activity is associated with decreased water temperatures (unpublished data, J. Gutiérrez and J. Zaldívar-Rae, Anáhuac Mayab University), and they seem to spawn throughout the year (Álvarez-Añorve et al. 1989; Barba-Macias et al. 1988; Bonilla-González et al. 1986; Rosales-Raya 1999). However, a markedly seasonal winter-spring spawning pattern, with a peak in December, was recently detected in Chuburná, on the northern coast of the peninsula (unpublished data, J. Gutiérrez and J. Zaldívar-Rae, Anáhuac Mayab University), a pattern that seems to be the rule for all localities along that stretch of coast (J. Zaldívar-Rae, personal observations).

Daily spawning activity is associated with high tides, which they detect through changes in water depth (Chabot et al. 2008; Chabot and Watson 2010; Chabot et al. 2011). Some observations suggest that horseshoe crabs prefer to spawn around the time of the new and full moon high tides, which are the highest tides of the month (Rudloe 1980; Brockmann 2003b; Barlow et al. 1986; Brockmann and Johnson 2011; Smith et al. 2002b, Chabot et al. 2008; Watson and Chabot 2010). However, other studies have reported that the association between spawning activity and the lunar period is not strong or only slightly higher than expected by chance alone (Smith et al. 2010; Cheng et al. 2016) and that spawning occurs at a similar intensity during all daytime high tides regardless of lunar phase (James-Pirri et al. 2005; Leschen et al. 2006). In some areas horseshoe crabs seem to prefer the higher of the two daily tides regardless of light:dark cycle (Barlow et al. 1986; Rudloe 1980; Chabot and Watson 2010; Brockmann and Johnson 2011). In Great Bay Estuary in NH, spawning activity was similar during daytime and nighttime high tides (Watson and Chabot 2010; Cheng et al. 2016). In Delaware, the greatest spawning activity occurs during the evening high tides (Shuster and Botton 1985; Smith et al. 2010). In microtidal areas, such as Indian River Lagoon, Florida, breeding activity is episodic (Ehlinger et al. 2003), or breeding activity is affected by increased water level from wind-blown surge, such that deeper water results in a larger number of crabs (Rudloe 1985). Even where there is a $1 \mathrm{~m}$ tidal inundation, higher water levels from wind-blown surge strongly influence the numbers of spawning horseshoe crabs (Brockmann and Johnson 2011).

\section{Spawning habitat}

Spawning adults prefer sandy beach areas within bays and coves that are protected from wave energy (Shuster and Botton 1985; Smith et al. 2002a; Jackson et al. 2002; Landi et al. 2015). Nests are primarily located between the low-tide terrace (tidal flat) and the extreme high-tide water line (Penn and Brockmann 1994; Weber and Carter 2009). Weber and Carter (2009) found that $85 \%$ of nests were deposited on the foreshore between the tidal flat and the nocturnal hightide wrack line on the western shore beaches of Delaware Bay. Penn and Brockmann (1994) noted that nests occurred in a narrower band along the high-tide line of beaches on the west coast of Florida. On the Yucatán Peninsula, horseshoe crabs spawn on small beaches limited by mangroves or near the edges of small mangrove islands within coastal lagoons where organic matter abounds and microbial decomposition is high (Zaldívar-Rae et al. 2009). Spawning is sometimes observed on offshore sandbars and oyster bars (Wenner and Thompson 2000). On the Mississippi coastal islands, breeding occurs primarily on the protected north sides of intertidal sand beach habitat (Fulford and Haehn 2012). Some sub-tidal nesting also occurs in sands with high oxygen, such as the sand flats just off the beach. Most nesting beaches have nearby nursery habitats for juveniles (Botton and Loveland 2003). Geographic differences in nest site selection can be explained by differences in wave energy, beach morphology, and geochemistry (Botton et al. 1988; Penn and Brockmann 1994; Smith et al. 2002a; Beekey and Mattei 2009; Landi et al. 2015). Sediment grain size, in particular, can influence spawning site selection as environmental conditions in the sand 
affect development (moisture, temperature, and oxygen gradients) (Penn and Brockmann 1994; Jackson et al. 2008). Previous studies suggest that females avoid laying eggs in eroded beaches that are high in hydrogen sulfide and where sediment pore water is low in oxygen, factors that are known to affect development (Botton et al. 1988; Penn and Brockmann 1994; Vasquez et al. 2015a) In Massachusetts, New Jersey, and Delaware, spawning beaches are typically coarse-grained and well drained, as opposed to Florida beaches, which are typically fine-grained and poorly drained (Penn and Brockmann 1994). In Long Island Sound, nests can be found on beaches ranging from coarse-grained and well drained to cobble-dominated substrates to fine grained and poorly drained muddy substrates (Beekey and Mattei 2009). In Yucatán, spawning pairs seem to prefer the high tide line of beaches where coarser sand and rubble are mixed with the more common fine sand/clay substrates, usually at the base of man-made structures and roadsides that reach the water ( $\mathrm{J}$. Gutiérrez and J. Zaldívar-Rae, Anáhuac Mayab University, personal communication). In the Laguna de Términos and Champotón areas of Campeche, México, substrate composition in nesting sites varies widely, from an estuarine locality (Icahao, near Champotón) where up to $60 \%$ of the substrate was medium-grain to cobble, to a coastal lagoon site (Isla Pájaros, in Laguna de Términos) where $70 \%$ of the substrate was loam-clay to fine sand (Rosales-Raya et al. 1997).

\section{Mating}

Female crabs typically arrive at the spawning beach each with a male attached to her posterior opisthosomal spines (Cohen and Brockmann 1983; Loveland and Botton 1992; Brockmann 2003a; Shuster 1982). In addition, unattached males come to the shore and gather around nesting pairs as satellites (Cohen and Brockmann 1983; Brockmann and Penn 1992). Males in amplexus do not differ in size from unattached males, but they are in better condition, more active, have a higher sperm concentration, remain attached longer and probably are younger (more recently molted into the adult) than satellite males (Cohen and Brockmann 1983; Brockmann and Penn 1992; Loveland and Botton 1992; Brockmann 2002; Duffy et al. 2006; Sasson et al. 2012). Satellite males are rare in some populations, including the Florida Atlantic and the northern coast of the Yucatán Peninsula including Chuburná and Chabihau (unpublished data J. Gutiérrez and J. Zaldívar-Rae, Anáhuac Mayab University). Although a single attached male can fertilize all of the eggs, when satellite males are present (often two to four), they may fertilize a majority of the eggs (Brockmann et al. 1994, 2000). Single females have been observed excavating nests on spawning beaches in Long Island Sound where spawning indices are extremely low (0.002 females $\mathrm{m}^{-2}$ ); however, it is unknown whether eggs were deposited or not (Mattei et al. 2010). Elsewhere, when females arrive on the beach without males, they do not lay eggs (Brockmann 1990).

Operational sex ratios (OSR), which are the observed ratios for spawning horseshoe crabs, are typically male biased (Cohen and Brockmann 1983; Loveland and Botton 1992; Brockmann and Smith 2009; Mattei et al. 2010; Beekey and Mattei 2015). Unattached males return to the beach more frequently than females, creating male-biased OSR and male-male competition for mates (Rudloe 1980; Brockmann 1990; Smith et al. 2002a, 2010; Brockmann and Smith 2009; Brockmann and Johnson 2011). The mean OSR in unharvested populations is generally 1.5-2.4 males to females (Rudloe 1980; Wenner and Thompson 2000; Schaller 2002; Brockmann and Johnson 2011), but in populations with female-biased harvest the sex ratio is elevated, i.e., 3 to 8 males/female (Smith et al. 2002b, 2009a; Carmichael et al. 2003; James-Pirri et al. 2005; Kreamer and Michels 2009). Mean OSR during the 2012-2013 spawning season in Chuburná, Yucatán, was 1.1 males to females (unpublished data, J. Gutiérrez and J. Zaldívar-Rae, Anáhuac Mayab University).

\section{Egg deposition}

Horseshoe crabs are the only extant marine arthropod with external fertilization that do not brood their eggs (Brusca and Brusca 2003). On spawning beaches, females excavate a pit below their body and deposit two to five separate clusters of eggs at depths from 5 to 20 cm (Rudloe 1979; Brockmann 1990; Leschen et al. 2006; Brockmann 2003b). Horseshoe crab fecundity varies with latitude and with female size (Botton et al. 2010). Shuster (1982) reported 88,000 eggs per female 
for the Delaware Bay. Average fecundity was correlated with female size in Pleasant, Bay Massachusetts with fecundity ranging from 14,500 eggs for a $201 \mathrm{~mm}$ prosomal width (PW) female to 63,500 eggs for females $>261 \mathrm{~mm}$ PW (Leschen et al. 2006). Males externally fertilize the eggs as the female deposits them. Nearly all eggs are fertilized regardless of whether satellite males are present $(96.8 \%)$ or not (96.4\%) (Johnson and Brockmann 2010).

Cluster size also varies with latitude. In Florida, cluster size was reported to be $1644 \pm 103$ for singly mated females and $1739 \pm 93$ for females with satellites (Johnson and Brockmann 2010) rising to 2365-5836 eggs/cluster in Delaware Bay (Shuster and Botton 1985; Weber and Carter 2009). In Long Island Sound, cluster size averages 3741 eggs (Beekey et al. 2013) compared to 640-1280 in Cape Cod (Leschen et al. 2006). Cluster size is not correlated with female size (Brockmann 1996; Leschen et al. 2006), but larger females lay more clusters per spawning season than smaller females. Females typically lay multiple nests during one tidal cycle (5 days of extra-high tides around the new or full moon) (Brockmann and Penn 1992; Brousseau et al. 2004; Smith et al. 2010; Beekey and Mattei 2015). Brockmann (1990) reported that in Florida, females returned to nest on average 3.4 times and most spawned during only one tidal cycle, whereas males returned over two or more tidal cycles (Brockmann and Penn 1992). In Delaware Bay females spawned over two to five consecutive nights, remaining within $50-715 \mathrm{~m}$ of their established spawning beach before moving away from the beaches several days after the tidal cycle (Brousseau et al. 2004; Smith et al. 2010). In Long Island Sound, females can typically be found returning to nest at the same beach up to six days after their initial appearance (Beekey and Mattei 2015).

\section{Development and growth}

Egg development is affected by temperature, salinity, moisture, and oxygen (Vasquez et al. 2015b). Trilobite larvae hatch from the eggs within 2-4 weeks, although some larvae may overwinter within nests and hatch out the following spring (Botton et al. 1992). Hatching is triggered by environmental cues associated with high water conditions (hydration, physical disturbance, hypoosmotic shock), which helps to maximize survival by preventing larvae from being stranded on the beach (Ehlinger and Tankersley 2003; Botton et al. 2010). Trilobite larvae are weak swimmers and rely on vertical movement to take advantage of selective tidal stream transport. Larvae settle within a week of hatching and begin molting (Shuster 1982). Larval and juvenile crabs remain in the intertidal flats, usually near breeding beaches suggesting limited larval dispersal (Botton and Loveland 2003; Cheng et al. 2015). Approximately 2 weeks after hatching, larvae molt to the juvenile stage (second instar stage) when the telson is formed. Many juveniles reach the fourth instar by the end of their first summer (Botton et al. 1992). Over time, the older juveniles move out of intertidal areas to deeper waters (Botton and Ropes 1987) where they remain until they reach maturity.

Horseshoe crabs undergo stepwise growth, shedding their exoskeleton at least 16 or 17 times before reaching sexual maturity (Shuster 1950), a process that takes 9-10 years (Shuster and Sekiguchi 2003). Females are typically larger at maturity than males, which is thought to be due to one additional molt (Smith et al. 2009a). Smith et al. (2009a), reviewing several studies, reported the average prosomal width growth increment (ratio of PW from instar $i$ to $i+1$ ) for all instars was 1.28 (range 1.15-1.52). Growth is relatively rapid during the first several years, progressing through stages I-V in the first year, stages VIVII the second year, stages VII-IX the third year, with a single molt per year after that until reaching maturity (Shuster 1982). The pattern of development appears to the same throughout the species' range despite large regional differences in environmental attributes (Estes et al. 2015; Carmichael et al. 2003). Shuster (1950) approximated that it took 9-12 years for horseshoe crabs to reach sexual maturity. Sekiguchi et al. (1982) concluded that Limulus polyphemus molts 16 times and matures in their ninth year and that females molt 17 times and mature in their tenth year. Smith et al. (2009a) found that males in Delaware Bay tended to mature at ages 10 and 11 , while females tended to mature at ages 10, 11 and 12. Cheng et al. (2015) found that males matured after about 17 molts (approximately 9 years), and females matured after about 18 molts (approximately 10 years). Marked adults have been observed over 6-10 years, which means that some individuals may reach at least 20 years of age (Shuster 1958; Ropes 1961; Botton and Ropes 1988; Grady et al. 2001; Swan 2005; Brockmann and Johnson 2011; Beekey and Mattei 2015). Horseshoe 
crabs attain largest average size at the central portion of their range (Delaware Bay) and are significantly smaller north of Long Island Sound and in the Gulf of México (Shuster 1979; Graham et al. 2009; Smith and Brockmann 2014) and México.

\section{Migration and dispersal}

The general movement patterns of horseshoe crabs include: (1) juveniles move from spawning beaches to deeper waters as they age, (2) juveniles reach sexual maturity in their natal estuary or migrate to deeper waters to mature, and (3) adults migrate annually from the deeper waters to spawn on estuarine beaches (Baptist et al. 1957; Shuster 1979; Shuster and Botton 1985; Botton and Ropes 1987; Botton and Loveland 2003; Smith et al. 2009a). Whether they move into deeper waters within the natal estuary or move into the adjacent ocean is population dependent. Along the Mid-Altantic coast, many populations migrate to the ocean. While the greatest proportion of the Delaware Bay horseshoe crabs appear to migrate to the continental shelf (Botton and Ropes 1987; Hata and Hallerman 2008), tagging data indicate that some Delaware Bay crabs and most crabs across the New England States remain within local regions and overwinter in local embayments (Botton and Ropes 1987; James-Pirri et al. 2005; Swan 2005; Smith et al. 2006; Moore and Perrin 2007; Beekey and Mattei 2009; Schaller et al. 2010; Beekey and Mattei 2015). Landi et al. (2015) found that spawning beach locations within Long Island Sound tended to be those closer to offshore locations where adults were caught in trawl surveys. These data are further supported by stable isotope analyses, which indicate that adult crabs are loyal to local feeding grounds (Carmichael et al. 2004; O'Connell et al. 2003). Smith et al. (2006) estimated that approximately $1 / 3$ of adults overwintered in Delaware Bay and did not migrate to the ocean. Finally, acoustic telemetry data and tracking studies have shown that many animals remain yearround within one bay or estuary (Rudloe 1980; Ehlinger et al. 2003; Beekey and Mattei 2009; Schaller et al. 2010; Watson et al. 2016). Smith et al. (2009a) suggested that horseshoe crabs in Delaware Bay exhibit sex-specific migratory patterns. Until about age 8 years, juveniles of both sexes tend to remain within the bay. After age 8 years, females begin to migrate at a higher rate than males to the continental shelf as older juveniles and mature in the ocean. In contrast, males tend to reach sexual maturity without leaving the bay. After reaching maturity, both sexes migrate from the ocean or deep bay waters to spawn on the estuarine beaches.

\section{Mortality}

Factors contributing to natural mortality include age and stranding during spawning, which can result in desiccation and predation. Loveland et al. (1996) reported that the natural mortality rate in adults is low with the single greatest source due to beach stranding. Botton and Loveland (1989) concluded that stranding mortality, which they estimated to be about $10 \%$ of the total adult population in Delaware Bay in the mid1980 s, is likely to vary among estuaries because it is affected by population density, weather and tidal conditions, and beach geomorphology. The condition of the individual, which is probably age related, is also a factor in stranding-related mortality (Penn and Brockmann 1995; Smith et al. 2010). Carmichael et al. (2003) found that in Pleasant Bay, Massachusetts, adults had a lower estimated mortality rate than juveniles, and there was no significant difference in estimated mortality rate for adult males and females. In contrast, Butler (2012) found through analysis of mark-recapture data from Delaware Bay that adult male annual survival $(77 \%, \mathrm{SE}=0.04)$ was greater than adult female survival $(65 \%, \mathrm{SE}=0.09)$. Adult and juvenile horseshoe crabs make up a portion of the loggerhead sea turtle's (Caretta caretta) diet in the Chesapeake Bay (Keinath 2003; Seney 2007), but the severity of horseshoe crab mortality due to predation from sea turtles, alligators in the southeast (Reid and Bonde 1990), and other marine animals remains unknown. In Bocas de Dzilam, Yucatán, and the Yalahau lagoon, Quintana Roo, raccoons (Procyon lotor) actively search for and prey upon spawning pairs and solitary individuals approaching the wrack line (J Zaldívar-Rae, personal communication).

Shorebirds feed on horseshoe crab eggs in areas of high spawning densities such as the Delaware Bay (Botton et al. 1994, 2003). Horseshoe crab eggs are considered essential food for several shorebird species in the Delaware Bay, which is the second largest migratory staging area for shorebirds in North America (Clark and Niles 1993; Haramis et al. 2007). Despite significant shorebird predation on horseshoe 
crab eggs, such activity probably has little impact on the horseshoe crab population (Botton et al. 1994). Horseshoe crabs deposit eggs at 5-25 cm deep (Weber and Carter 2009), which is beyond the reach of most short-billed shorebirds. Many eggs are brought to the surface by wave action and the burrowing activities of spawning horseshoe crabs (Nordstrom et al. 2006). These surface eggs that are consumed by birds would not survive, due to desiccation (Botton et al. 1994). Horseshoe crab eggs and larvae are also a seasonally preferred food for a variety of invertebrates and finfishes (Shuster 1982). In Florida, where many shorebirds winter particularly along the west coast (Sprandel et al. 1997), as well as Long Island Sound where shorebirds stop over on their northward migration, populations of horseshoe crabs are relatively small, so their eggs provide a less dependable food source than in Delaware Bay, so the presence of horseshoe crab eggs in the diet of Florida or Long Island shorebirds is considered to be opportunistic (Gerhart 2007; Beekey et al. 2013).

\section{Habitat requirements}

Limulus polyphemus tolerates a broad range of environmental conditions, although individual sub-populations may have narrower tolerances than the species as a whole (Shuster and Sekiguchi 2009). Habitat requirements change throughout the horseshoe crab life cycle.

\section{Larval habitat requirements}

Nest depth on the western shore of Delaware Bay ranged between 3.5 and $25.5 \mathrm{~cm}$ (mean 15.5, SD 3.5), although nest depth may be affected by wave energy, bioturbation, or other factors after deposition (Weber and Carter 2009). These results are similar to those found by previous investigators on Delaware Bay beaches (e.g., Hummon et al. 1976; Penn and Brockmann 1994; Botton et al. 1994). In the Laguna de Términos and Champotón areas of Campeche, México, nest depths range from 2 to $30 \mathrm{~cm}$ (Rosales-Raya et al. 1997).

The rate of egg development is dependent on interstitial environmental parameters including temperature, moisture, oxygen, and salinity (French 1979; Jegla and Costlow 1982; Laughlin 1983; Penn and Brockmann 1994; Vasquez et al. 2015a) and disturbance (bioturbation) from external forces (Jackson et al. 2008). Optimal development occurs at salinities between 20 and 30 ppt (Jegla and Costlow 1982; Laughlin 1983), although populations from microtidal lagoon systems that often experiences high salinities ( $>50 \mathrm{ppt}$ ) had an optimal range of 30-40 ppt, with hatching occurring at salinities as high as $60 \mathrm{ppt}$ (Ehlinger and Tankersley 2004, 2009). In Campeche, México, the salinity of interstitial water surrounding nests ranged from 25 to 59 ppt (Rosales-Raya et al. 1997). Egg development occurs more quickly at temperatures ranging from 25 to $30{ }^{\circ} \mathrm{C}$ (Jegla and Costlow 1982; Laughlin 1983; Penn and Brockmann 1994; Ehlinger and Tankersley 2004). Penn and Brockmann (1994) found the optimal development of horseshoe crab eggs from Delaware and Florida to occur at oxygen concentrations between 3 and 4 ppm and moisture content between 5 and $10 \%$. Vasquez et al. (2015a) demonstrate that embryonic development of horseshoe crabs is significantly reduced by exposure to stressors (low salinity, low oxygen, high $\mathrm{H} 2 \mathrm{~S}$, low temperatures) that occur at low beach elevations and that these stressors (e.g. low oxygen and high temperature) interact synergistically (Vasquez et al. 2015b).

\section{Juvenile habitat requirements}

Nearshore, shallow water, intertidal flats are essential habitats for the development of juvenile horseshoe crabs since juveniles usually spend their first 2 years on the sand and mud flats just off the breeding beaches (Rudloe 1981; Shuster and Sekiguchi 2009). The diet of juveniles is varied, including particulate organic matter from algal and animal sources (Gaines et al. 2002; Carmichael et al. 2004). Delaware Division of Fish and Wildlife's 16-foot bottom trawl captured $\geq 99 \%$ of juvenile horseshoe crabs $(<16 \mathrm{~cm}$ prosomal width) at salinities $>5 \mathrm{ppt}$ and $\geq 95 \%$ at salinities $>15$ ppt (Michels 1996; unpublished data S. Michels, DE DFW). In the southeast, juveniles have been reported to be active throughout the year, foraging in the intertidal zone within a few meters of the nesting beach (Rudloe 1981). They alternately crawl on the surface of the substrate and bury in the sand or mud, feeding on benthic organisms. In the Delaware Bay, females begin to leave the Bay and move to continental shelf waters around age 7-8 where they mature in the ocean (Hata and Hallerman 2009; Smith et al. 
2009a). Smith et al. (2009a) provide evidence that males remain in the Bay until maturity (age 9), but Hata and Hallerman (2009) found evidence of significant numbers of immature males on the shelf 1-2 years before reaching maturity. As horseshoe crabs mature, the diet composition shifts to larger prey, and horseshoe crabs are known to be important predators of benthic meiofauna (Carmichael et al. 2004, 2009; Botton 2009).

\section{Adult habitat requirements}

Adult horseshoe crabs have been found as far as 35 miles offshore at depths greater than 200 meters; however, Botton and Ropes (1987) found that 74 percent of the horseshoe crabs caught in bottom trawl surveys conducted by the NOAA Fisheries, Northeast Fisheries Science Center were taken in water shallower than 20 meters. They occupy a broad range of salinity regimes, from low salinity $(<10 \mathrm{pp})$ areas such as the upper Chesapeake Bay to the hypersaline ( $>50$ ppt) environments of the Indian River Lagoon in Florida. During the spawning season, adults typically inhabit bay areas adjacent to spawning beaches. In Delaware Bay, horseshoe crabs are active in the Bay area at temperatures above $15^{\circ} \mathrm{C}$ (Shuster and Sekiguchi 2009; Smith et al. 2010), while crabs in Great Bay, NH increase activity at temperatures above $10.5^{\circ} \mathrm{C}$ (Watson et al. 2009). In the fall, adults may remain in local embayments or migrate offshore to overwinter on the continental shelf. The northern range extent may be limited by duration and severity of winter temperatures. The lack of horseshoe crab populations in the western Gulf of México, which has suitable beach spawning habitat, may result from the local hydrodynamic and tidal regime along with an absence of barrier islands to attenuate wave energy (Ruth Carmichael, Dauphin Island Sea Lab, personal communication). Nearly all horseshoe crab populations occur in areas with semi-diurnal tides of moderate amplitude, which do not occur in the western Gulf of México. However, two populations of horseshoe crabs, Indian River and St. Joe Bay populations occur in microtidal environments (Ehlinger et al. 2003; Rudloe 1985), so clearly tides are not a prerequisite for horseshoe crabs. On the western coasts of the Gulf of Mexico, mixed diurnal microtidal regimes predominate (Silva-Casarín et al. 2014, Secretaría de Comunicaciones y Transportes 2016).
Horseshoe crab populations in Florida occur in areas with semidiurnal tides (Tenorio-Fernandez et al. 2015), while horseshoe crab populations of the west and north coasts of the Yucatan Peninsula live predominantly under diurnal microtidal regimes (Mariño-Tapia et al. 2011; Cuevas-Jiménez and Euán-Ávila 2009; Silva-Casarín et al. 2014; TenorioFernandez et al. 2015).

Adult horseshoe crabs are known to be important predators of a variety of benthic macrofauna (Carmichael et al. 2004, 2009; Botton 2009). Botton and Haskins (1984) and Botton and Ropes (1989) found that the primary prey for adult horseshoe crabs are blue mussels (Mytilus edulis) and surf clams (Spisula solidissima).

In summary, horseshoe crabs are an important part of the ecology of the coastal systems in which they are found (Botton 2009). They are prey for endangered sea turtles (Keinath 2003; Witherington and Witherington 2015), and their eggs are consumed by migrating shorebirds (Haramis et al. 2007). Their burrowing activities affect the habitat available for other species through bioturbation (Gilbert and Clark 1981; Kraeuter and Fegley 1994), and predatory activities affect the intertidal and subtidal meio- and macrofauna (Wenner and Thompson 2000; Ehlinger and Tankersley 2009).

\section{Major threats}

\section{General}

The major threats to the American horseshoe crab (i.e., those stressors that could impact population viability and lead to regional or species extinction) are commercial harvest for bait, production of a biomedical product, and marine life specimens for research, education, and aquaria (Grady and Valiela 2006; Davis et al. 2006; Brockmann et al. 2015), spawning habitat loss (Botton et al. 1994; Jackson and Nordstrom 2009), pollution (Venosa et al. 1996; Strobel and Brenowitz 1981; Botton and Itow 2009), bycatch (Gerhart 2007), impingement by coastal infrastructure (including power plants) and climate change (Loveland and Botton 2015). Also, an emerging threat is the importation of Asian species for use as bait in the whelk and eel fisheries in the Mid-Atlantic region with the associated risk of introduction of pathogens, 
parasites, and non-native species (Botton et al. 2015). The significance of each threat varies over time and among regions.

\section{Commercial harvest}

American horseshoe crabs are commercially harvested. Currently, most are harvested for use as bait in other fisheries (eel and whelk in the United States). Harvest by the biomedical industry for the production of Limulus amebocyte lysate (LAL) is significant and increasing, but currently less than for bait and does not result in 100\% mortality as does bait harvest (ASMFC 2013). Harvest for the marine life aquaria trade or scientific and educational collection is small in comparison to other uses, but is significant in Florida where juveniles are collected in large numbers (Gerhart 2007). Substantial evidence suggests that overharvest can result in depleted populations and localized extirpations (Widener and Barlow 1999; Carmichael et al. 2003; Rutecki et al. 2004; Schaller et al. 2005; Gerhart 2007; Smith et al. 2009b; McGowan et al. 2011b).

\section{Bait harvest}

Historically, horseshoe crabs in Delaware Bay were harvested (1 to 5 million per year) for fertilizer dating back to the mid-1800s (Shuster and Botton 1985). Harvest of horseshoe crabs for fertilizer declined to a negligible level by the 1960s (Shuster 2003; Kreamer and Michels 2009).

Presently, the largest harvest of horseshoe crabs is for use as bait in the conch (Busycon spp.) pot and American eel (Anguilla rostrata) fisheries (ASMFC 2009). The increase in harvest of horseshoe crabs during the 1990s is due in large part to increased demand for whelk bait (Smith et al. 2009b). Coastwide landings of all four whelk species have increased $62 \%$ since 2005 (ASMFC 2013), although harvest of horseshoe crabs for bait has declined since 1998 through quota regulations and has been stable since the mid-2000s (Eyler et al. 2015).

Between 1970 and 1990, annual commercial harvest ranged from less than $20,000 \mathrm{lb}(9 \mathrm{mt})$ to above 2 million pounds (907 mt) (ASMFC 2009). Reported harvest increased rapidly during the late 1990 s to over 6 million pounds $(2722 \mathrm{mt})$ or 3 million animals in 1998 (Eyler et al. 2015). Since 1998, the Atlantic
States Marine Fisheries Commission and the respective states have set harvest quotas and season closures (ASMFC 1998), NOAA Fisheries established a marine reserve, and commercial fishers have made widespread use of bait-saving devices. In recent years, reported bait landings ranged from 600,000 to 750,000 animals, and more males have been harvested than females because states have established sex-specific restrictions designed to reduce harvest of females (ASMFC 2013).

In Northeast Gulf region, harvesting of horseshoe crabs by shrimp trawlers began in the early 1980s as the need for bait in the whelk fishery increased (Rudloe 1982). In 1999, more than 110,000 horseshoe crabs were harvested from the northwest coast of Florida. In that year, fishermen were experiencing a bait shortage due to increased regulation of horseshoe crabs in Delaware Bay, and an estimated 99,000 horseshoe crabs were collected in 44 days (Wallace 1999). Since 2000 , only 14,683 horseshoe crabs have been harvested for bait along the west coast of Florida based on data compiled from reported trip tickets (Gerhart 2007; Brockmann et al. 2015). Bait harvest in Florida is regulated and does not present a threat at this time. Because of the low numbers of horseshoe crabs in the other Gulf of Mexico states, there are no regulations and no known harvest.

Although horseshoe crab harvesting is illegal in México due to the species' risk status (see below), there are increasing reports of small-scale poaching of adults by local watermen who set shallow-water nets at the mouths of coastal lagoons during the incoming phase of the tidal cycle and hand-pick the animals (Zaldívar-Rae, Anáhuac Mayab University, personal communication). In Chuburná, Progreso-Yucalpetén, Telchac, Chabihau and Río Lagartos, Yucatán, this activity coincides with the horseshoe crab spawning season (Zaldívar-Rae, Anáhuac Mayab University, personal communication), and anecdotal accounts suggest this harvest occurs in other localities. Illegally harvested horseshoe crabs are sold clandestinely and used solely as an alternative to commercial bait species (Libinia dubia and Cardisoma guanhumi crabs) in the artisanal octopus (Octopus maya) fishery of Campeche and Yucatán, which takes place between August and December. According to accounts from locals, ship owners and seafood merchants buy horseshoe crabs from poachers and supply them to hired fishermen who catch common octopus (Octopus 
vulgaris) in deep waters during weeks-long trips. This has created a growing demand for large amounts of male horseshoe crabs, as their size is optimal to catch octopus with the traditional drifting technique ( $\mathrm{J}$. Zaldívar-Rae, Anáhuac Mayab University, personal communication). Illegal harvest, sale and purchase of horseshoe crabs are Federal felonies under Mexican law and are punished with up to 12 years of incarceration and fines of up to US\$19,000 (Diario Oficial de la Federación 2014a).

\section{Biomedical harvest}

Horseshoe crabs are harvested by the biomedical industry for the manufacture of LAL, which is used to test for gram-negative bacterial contamination in injectable drugs, vaccines, and implantable medical devices. The LAL test was commercialized in the 1970s and is currently the global standard for screening medical equipment and all injectables for bacterial contamination (Levin et al. 2003). Gauvry (2015) forecasts increased demand for LAL over the next decades due, in part, to projected growth in the demand for vaccines in emerging markets coupled with the overharvest of Asian horseshoe crab populations especially Tachypleus tridentatus, the source of TAL, which is an alternative to LAL. The depletion of TAL could shift the world-wide demand for amebocyte lysate onto the American horseshoe crab.

Blood from horseshoe crabs for LAL production is obtained by collecting adult crabs, extracting a portion of their blood $(<40 \%$ of blood volume; Hurton and Berkson 2006), and releasing them alive. The US Food and Drug Administration (FDA) estimated medical usage increased from 130,000 crabs in 1989 to 260,000 in 1997 (D. Hochstein, FDA, Center for Biologics Evaluation and Research, personal communication) with a steady increase since that time; in 2014 , over 500,000 crabs were used for LAL production-a 285\% increase from 1989 (Eyler et al. 2015). Bleeding facilities for the production of LAL harvest from: Massachusetts and Rhode Island waters (Associates of Cape Cod); Delaware, Maryland, or Virginia waters (Limluli Laboratories, Lonza Walkersville Inc., Wako Chemicals, and Heptest Laboratories); and South Carolina waters (Charles River EndoSafe).

Based on a review of pertinent studies (Rudloe 1983; Kurz and James-Pirri 2002; Walls and Berkson 2003; Hurton and Berkson 2006; Leschen and Correia
2010), the ASMFC assumes a $15 \%$ post-release, postbleeding mortality with a range of 5 to $30 \%$ mortality depending on factors such as volume bled and handling stress. Under these assumptions, estimated mortality of crabs processed for LAL for 2012 was 79,786 with a range of 31,189-152,681 crabs, which represents up to $17 \%$ of total harvest (ASMFC 2013; Eyler et al. 2015; Millard et al. 2015). Mortality due to biomedical harvest increased by $78 \%$ from 44,830 in 2005 to 79,786 in 2012 (Gauvry 2015). Sublethal effects of bleeding on individuals, such as reduced activity, have been documented (Anderson et al. 2013), and population-level effects, such as reduced spawning, in areas open only to biomedical harvest have been observed (James-Pirri et al. 2012; Novitsky 2015).

Although coast-wide biomedical harvest is reported to ASMFC (Eyler et al. 2015), region specific biomedical harvest is not publically available due to confidentiality agreements (Novitsky 2015). This practice prevents accounting for mortality due to biomedical activity in regional assessments and harvest management (Millard et al. 2015). Biomedical harvest has exceeded the de minimis threshold to avoid regulatory attention since 2007 (Eyler et al. 2015), but ASMFC has not yet acted on that exceedance. Novitsky (2015) calls for "open" reporting of biomedical harvest and updating of enforceable LAL-industry best management practices (BMP) to support conservation of regional and embayment specific populations.

Marine life and scientific collection

Horseshoe crabs are collected for marine life fishery (e.g., aquarium trade for display in public aquaria or study by students) and scientific collection. Atlantic states are required to report all harvest, including harvest for marine life or scientific collection, to show compliance with the Fishery Management Plan (Marin Hawk, ASMFC, personal communication). The required monitoring report from 2012 indicates that marine life or scientific collection not associated with biomedical harvest involves a few permits issued and relatively small numbers of animals kept (ASMFC 2013). For example in 2012, Massachusetts reported fewer than 1000 collected; Connecticut reported that collections were for educational purposes and individuals were returned to open water alive; New Jersey 
reported a few hundred were collected and most were returned alive; Delaware reported fewer than 300 collected mostly for research and education; and North Carolina reported approximately 500 collected with half returned alive. The exception is Florida, where the marine life fishery is substantial and may be expanding on the west coast, but may be declining on the east coast (Florida harvest data file compiled from trip tickets; Brockmann et al. 2015). On the east coast from 2008 to 2013, a mean of 109 trips have collected a mean of 4938 animals per year (mean 45.3 animals per trip). Although these numbers are small and have declined substantially since 2004, the east coast populations of horseshoe crabs are small and could be affected significantly by this harvest. On the west coast from 2008 to 2013, a mean of 264 collecting trips have been made annually with a mean of 22,597 animals collected per year (mean 85.5 animals per trip). The magnitude of the threat from the marine-life fishery is unknown because population size is unknown (Gerhart 2007). However, approximately half of reported marine-life landings of horseshoe crabs are from the Florida Keys (49\%; FWC on-line survey), which have low numbers of horseshoe crabs and a dearth of suitable adult spawning habitat. If the current population abundance is indeed low, extensive removal of largely first or second-year juveniles due to marine-life landings could hamper the ability of the population to sustain itself (Gerhart 2007; Sweka et al. 2007; Brockmann et al. 2015).

\section{Bycatch}

Historically, horseshoe crabs have been considered bycatch in commercial fisheries targeted at other species and, as such, returned to the water (Walls et al. 2002). However, injuries can occur during capture, and these injuries can lead to mortality or diminished fitness. Horseshoe crabs were the most abundant invertebrate bycatch species caught in shrimp trawls in Tampa Bay; 2867 horseshoe crabs were caught during two sampling seasons with the largest catches in the fall (Steele et al. 2002). As part of a tagging study during which horseshoe crabs were caught using dredges (Smith et al. 2006), the injury rate was $11 \%$ (4459 out of 39,343; unpublished data D. Smith, USGS). A subjective assessment was that $6 \%$ of the total catch (i.e., 2542 out of 39,343) suffered an injury severe enough to cause mortality. These injury and mortality rates would apply to bycatch when dredges are used to harvest whelk and when bottom trawls are used to harvest horseshoe crabs for LAL production. The significance to population viability depends on the magnitude of bycatch mortality compared to population size and natural mortality. As with any additional threat to horseshoe crabs, the importance will be greater for a small population restricted to a single embayment than for a large migratory population.

Horseshoe crabs may have been a common bycatch species of shrimp trawlers in the southern Gulf of México, especially during the 1970s-1980s, when this fishery experienced a boom in the bay of Campeche and few controls on bycatch were in place. However, in a more recent study of bycatch composition among artisanal trawlers fishing Atlantic seabob, Xiphopenaeus kroyeri, in areas within the Laguna de Términos where horseshoe crabs are common, they were not among the invertebrates caught with prawn (WakidaKusunoki 2005). In the Progreso-Yucalpetén coastal lagoon, Yucatán, horseshoe crab adults and juveniles are common bycatch in throw-nets and small manual trawl-nets used to catch shrimp. These animals are considered a nuisance as they damage the nets, and are either sold as bait or released upon capture ( $\mathrm{J}$. Zaldívar-Rae, Anáhuac Mayab University, personal observations).

\section{Habitat loss}

The undisturbed sandy beach is considered to be optimal spawning habitat (Botton et al. 1988), and the availability of optimal spawning habitat can be a factor limiting population growth (Rudloe 1982; ASMFC 1998). Botton et al. (1988) reported that only $10.6 \%$ of Delaware Bay shore on the New Jersey side was optimal spawning habitat. Beach erosion and human development are coast-wide concerns for conservation of beach habitat for horseshoe crabs (Jackson and Nordstrom 2009). Loss of sand to erosion exposes parent material, such as peat or mud, which tend to be anoxic or low-oxygen environments unsuitable for egg development (Botton et al. 1988; Penn and Brockmann 1994; Jackson et al. 2008; Vasquez et al. 2015a). Human development per se is not necessarily a threat because horseshoe crabs will spawn on beaches in front of houses and do not avoid human activity. Some of the best beach habitats with the densest spawning occur on sandy barriers 
associated with coastal development (Jackson and Nordstrom 2009). However, beach driving, which is permitted on some beaches, can result in crushing of buried or stranded horseshoe crabs. Ehlinger and Tankersley (2007) attributed the loss of optimal spawning habitat within Indian River Lagoon, FL (IRL) to a buildup of "muck" and anoxic sediments along the shoreline associated with a dramatic increase in human population adjacent to the IRL (WoodwardClyde Consultants 1994).

Hardening the shoreline as a means of erosion control can result in the loss of habitat suitable for horseshoe crab spawning and egg development. Shoreline change is a function of both coastal geomorphology and human development, and the purpose of erosion control is mainly to protect human structures (Hapke et al. 2013). Protecting sandy barriers with hard structures, e.g., bulkheads and riprap, can lead to a loss of habitat for spawning and egg development by truncating the beach foreshore and creating structures that trap spawning horseshoe crabs and increase stranding mortality. Jackson et al. (2015) reported that $40 \%$ of shoreline within five New Jersey spawning beaches was fragmented by bulkhead segments and enclaves. Further, between 20 and $100 \%$ of bulkheads intersected below the spring wrack line, which directly constricts spawning (Jackson et al. 2015). Ehlinger and Tankersley (2007) attributed one cause of the loss of spawning habitat in the IRL to impoundments, which reduced horizontal and vertical diversity of the shoreline. In contrast, protection or restoration of coastal ecosystems can serve the purpose of reducing risk to vulnerable property (Arkema et al. 2013). Beach replenishment can restore or maintain quality habitat (Jackson and Nordstrom 2009) if designed to match natural sediment characteristics (Jackson et al. 2005a, b, 2007) and support sediment transport (Jackson et al. 2010). Importantly, projects need to be located and timed to avoid adverse effects on spawning activity and early life stages.

\section{Impingement by coastal infrastructure}

There has not been a comprehensive assessment of the extent of coastline with infrastructure that poses a risk to impinge horseshoe crabs. Within Delaware Bay, Botton et al. (1988) estimated that $10 \%$ of New Jersey shoreline was severely affected by bulkheading, and more recent estimates indicate that the influence of bulkheading along the New Jersey bay shore has increased (Jackson et al. 2015). Although the state of Delaware removed bulkheads along their shoreline, extensive impingement has been observed at breakwaters formed by riprap and road overwash at Mispillion Harbor and Port Mahon (D. Smith, USGS, personal observation).

In the Indian River, a total of 39,097 horseshoe crabs were trapped on the intake screens at the Florida Power and Light Cape Canaveral Plant (FPL) and 53,121 at the Orlando Utilities Commission Indian River Plant (OUC) over the 12-month period (unpublished report, Applied Biology Inc. 1980). A study conducted in 1975 estimated 69,662 at FPL and 104,000 horseshoe crabs were retained annually at the FPL and OUC intakes. This level of mortality can be a threat to a local population if not minimized by engineered solutions (Ehlinger and Tankersley 2007).

Solutions to reduce entrapment and mortality have been engineered for some existing and new power plants. For example, through a federally approved National Pollution Discharge Elimination System permitting program pursuant to the section 316(b) of the federal Clean Water Act, the Connecticut Department of Energy and Environmental Protection has required the design and installation of Aquatic Organism Return Systems (AORS) in order to minimize the mortality of aquatic organisms, including horseshoe crabs (Mark Johnson, CT DEEP, personal communication). The AORS and narrowing the space between the bars of intake trash racks was designed to reduce impingement of horseshoe crabs that had entered the cooling water intake forebays and return them to open water. One power plant required periodic monitoring and removal of sediment accumulation near the intake structure to minimize trapping of horseshoe crabs. Such mitigation measures can reduce horseshoe crab mortality at coastal power plants, but the status of mortality at many power plants is not reported.

Water quality and pollution events

Towle and Henry (2003) review the mechanisms by which horseshoe crabs cope with low oxygen environments, including rapid respiratory and physiological response to transient hypoxia. Botton and Itow (2009) reviewed studies on water quality and contaminant effects on horseshoe crab embryos and larvae. 
They concluded that current levels of contamination and water quality did not pose a population-level impact upon L. polyphemus. Botton and Itow (2009) reached a different conclusion for $T$. tridentatus an Asian species in Japan where they believe pollution, particularly mercury and tributylin, is contributing to population decline.

Eutrophication due to excess nutrient loading, particularly nitrogen from anthropogenic sources in adjacent watersheds, is pervasive among coastal systems where horseshoe crabs reside. While nutrient enrichment and shifts in food source are known to affect nearshore marine food-web dynamics, these factors have not been found to have a significant effect on horseshoe crab abundance and distribution (O'Connell et al. 2003, Carmichael et al. 2004). As a result, unique dietary signatures (based on stable isotope values) have been useful to demonstrate that horseshoe crabs show fidelity to food resources, regardless of the level of eutrophication.

Oil spills represent an acute threat, which depends on timing, magnitude, wind pattern, oil type, and other factors that contribute to bioremediation (Venosa et al. 1996). While Delaware Bay is a major seaway for transport of oil (Botton and Itow 2009) and has a history of oil spills, the effect on the horseshoe crab population has not been evident largely because the timing and spatial extent of the spills have not overlapped with horseshoe crab spawning. However, an oil spill that resulted in oil washing onto active spawning beaches could be catastrophic to a local population (Venosa et al. 1996). In addition to the obvious effect of oil-coated animals, studies have demonstrated effects of oil on growth and survival of eggs and early life stages. Laughlin and Neff (1977) observed reduced hatching success in horseshoe crab eggs exposed to $50 \%$ water-soluble fraction of No. 2 fuel oil and metabolic stress among 2nd instars at lower concentrations (5-10\% water-soluble fraction). Oil that does not reach the beaches during spawning and is not collected will weather and lose volatile compounds (Strobel and Brenowitz 1981). The heavier oil that remains can affect larval development and survival with a minimum lethal dose of $2.25 \mathrm{mg} / \mathrm{l}$ in suspension (Strobel and Brenowitz 1981). A study lead by Ruth Carmichael (Dauphin Island Sea Lab, person communications) examined potential effects of the Deepwater Horizon oil spill (DWHOS) on young horseshoe crabs within the northern Gulf of Mexico
(Estes et al. 2015). Comparison of molt patterns (size and timing) at Petit Bios Island, Mississippi before and following the DWHOS indicated no evidence of adverse effect to subadult survival. However, they lacked evidence to make inference about effects on spawning adults or population-level effects.

Red tides are harmful algal blooms caused by abnormally high concentrations of dinoflagellates. Red tides caused by Karenia brevis are common in the nearshore areas of the Gulf of México, particularly southwest Florida and in the Yucatán Peninsula where horseshoe crabs are common. Periodic red tides occur along Florida's west coast, and young horseshoe crabs are one of the affected species (Galtsoff 1949). In July 1999, an estimated 100,000 adult L. polyphemus died in the northern part of the Indian River and the southern portion of Mosquito Lagoon (Scheidt and Lowers 2001), although a link to algal blooms or pollution could not be established. In Yucatán, red tides are common, with the latest events taking place in 2003, 2008 and 2011. These last occurrences were due to blooms of Scripsiella trochoidea, Cylindrotheca clostridium and Nitzchia longissima, although other species were also detected (Ortegón et al. 2011; Herrera et al. 2010). There are reports of severe impacts of harmful algal blooms on commercially important fishes and benthic organisms such as octopus, O. maya, and sea cucumbers, Isostichopus badionotus in the northern coast of Yucatán (Zetina et al. 2009), whose distributions overlap that of horseshoe crabs, but effects on the latter, although likely, have not been measured.

\section{Climate change}

Adult horseshoe crabs, as well as embryos and larvae, are eurythermal (Botton and Itow 2009), so direct mortality from rising water temperatures is probably less of a threat to the species than sea level rise. The apparent threat of climate change to coastal habitat is the loss of spawning habitat due to sea level rise and storms (Arkema et al. 2013; Loveland and Botton 2015). Sea level rise will increase the rate at which these habitats disappear, and it will increase the likelihood that horseshoe crab spawning habitat becomes compressed between the rising sea and existing housing and other infrastructure (Loveland and Botton 2015). Over the last century, sea level has risen by $20-40 \mathrm{~cm}$ depending on coastal location, due 
to sea level rise and local sinking of land. Along the Florida shore, the sea level is rising $2.5 \mathrm{~cm}$ every 11-14 years. Other effects of climate change, such as increasing water temperatures and altered storm frequency and severity, could affect the timing and success of spawning activity in some regions. Changes in the timing of spawning activity would have uncertain consequences to horseshoe crab population viability, but could have ecosystem effects by creating mismatches in predator-prey dynamics, particularly those involving migratory shorebirds and horseshoe crab eggs (McGowan et al. 2011a; Smith et al. 2011). Recent declines in the surf clam population in the midAtlantic region could be due to climate-change induced increases in water temperatures during latesummer and fall (E. Powell, Rutgers University, personal communication); the effects of a declining prey base on horseshoe crab population carrying capacity are unknown.

\section{Population analyses}

Qualitative trends

The northern-most population of horseshoe crabs was studied for 10 years from 2001 to 2010 (Schaller 2011; Schaller and Dorsey 2011). The study included daily surveys in Taunton Bay, Maine during late May and June each year where 6964 spawning horseshoe crabs were tagged and released (sex ratio of 1.8 males to females). The authors were "cautiously optimistic" that the population in Taunton Bay was stable (Schaller 2011). Pete Thayer (Maine Department of Marine Resources, personal communications) stated that "Over the late 90s to late 2000s, horseshoe crabs were fished down a bit for eel bait until a seasonal closure regulation was enacted, from which point they appeared to be bouncing back in the survey's final years." Moore and Perrin (2007), who tracked horseshoe crabs in Taunton Bay during 2003-2005, observed no emigration, and thus considered the populations to be resident to the embayment.

From 2001 to 2004, spawning surveys were conducted at five sites in the Gulf of Maine to establish baseline data (Schaller et al. 2005). Schaller et al. (2005) remarked that horseshoe crab spawning density is sparse throughout Maine and that horseshoe crabs no longer use three historical spawning sites. Of the five sites surveyed in all years (2001-2004), counts of spawning horseshoe crabs increased at three and decreased at two.

Several lines of evidence suggest a decline in horseshoe crabs of Florida's Indian River Lagoon estuary (Ehlinger and Tankersley 2007). In the 1970s, efforts to collect sea turtles resulted in large numbers of horseshoe crabs being collected in the nets, but few were caught in the 1990s. Further, loggerhead sea turtles, which prey heavily on horseshoe crabs, were the predominant species in the Indian River Lagoon in the 1970s, but by the 1990s, there were mostly green sea turtles, which feed on plants (Provancha et al. 2006). Disease outbreaks (Scheidt and Lowers 2001), habitat destruction, marine life harvest and large numbers of horseshoe crabs killed at power plants all suggest that the Indian River population is likely in decline (Ehlinger and Tankersley 2007; Brockmann et al. 2015).

Population sizes in México were reported to have dwindled dramatically between the 1960s and the early 1990s, especially in the Laguna de Términos area (Gómez-Aguirre 1979, 1980, 1983, 1985, 1993). However, these claims were not based on formal quantitative surveys. The only formal quantitative survey of spawning events carried out so far in a Mexican locality revealed that abundances of reproductive individuals are relatively low: spawning pairs do not exceed the tens of pairs in a 100-m transect on a peak high tide (unpublished data, J. Gutiérrez and J. Zaldívar-Rae, Anáhuac Mayab University), and reports by locals from other sites suggest that this may be the case throughout most of the distribution in México (J. Zaldívar-Rae, Anáhuac Mayab University, personal communication). Moreover, spawning seems to be restricted to particular shore conditions within coastal lagoons, so the availability of suitable spawning habitat may also be limited.

The genetic analysis by Faurby et al. (2010) showed declines in population sizes throughout the species' distribution except in the geographically isolated Yucatán Peninsula, where population size increased. Observed demographic changes in the Mid-Atlantic occurred within the last 150 years. They conclude the changes were likely caused by anthropogenic effects, including past overharvest of the species for fertilizer, and current bait and biomedical harvest. 
Quantitative trends

Data were available from 40 fishery-independent data sets covering Mid-Atlantic and Florida regions (New Hampshire to Florida; regions as defined above and in Fig. 1) over a range of years. The fishery-independent datasets were selected by the Atlantic States Marine Fisheries Commission (ASMFC) for stock assessment (Sweka et al. 2013). For ASMFC to choose a dataset, it must be overseen or conducted by a state or federal agency or academic institution and come from a survey using standardized methodology and sampling design. The data came mostly from benthic trawls (27 datasets) with some seines ( 9 datasets) and spawning surveys (4 datasets). All the surveys encounter horseshoe crabs regularly and the respective state agencies rely on them to comply with ASMFC monitoring requirements. However, only the spawning surveys and one benthic trawl in the Delaware Bay area were specially designed to monitor horseshoe crabs (Smith et al. 2002b; Hata and Berkson 2004). The primary data were individual counts of horseshoe crabs within sampling units; the demographic (age-class, sex) and temporal and spatial resolution of each dataset are described in Sweka et al. (2013: Appendix B) and summarized in Table 3. The datasets are available from ASMFC (www.asmfc.org; info@asmfc.org).

We analyzed trends from each dataset and then used meta-analysis techniques to summarize inference at the regional or sub-regional level because the data came from many independent monitoring programs. We grouped the datasets from the Mid-Atlantic region into sub-regions because of geographic differences in harvest pressure and environmental conditions. The sub-regions were the New England states (NH, RI, MA), New York area (CT, NY), and Delaware Bay area (NJ, DE, MD, VA). Also, datasets represented the Southeastern (NC, SC, GA), Florida Atlantic (FL), and Gulf of México (FL) regions. There were no statespecific datasets from NC; however, data from an offshore monitoring program (SEAMAP) included waters off the NC coast. The New England area included the longest time series, with one data set from 1959 and several that began in the 1970s. Data sets from the New York and Delaware Bay areas began in the late 1980s. Data sets from the Southeast included several that started in the mid-1990s.

The objective of the meta-analysis of regional trends was to assess the change in horseshoe crab populations during the periods defined by the available data. The trend analyses involved fitting a linear regression to the data, which had been standardized by subtracting the mean and dividing by the standard deviation. The standardization was required for the trend analysis results based on individual datasets to be combined using meta-analysis techniques. Because there were multiple datasets per region, no one dataset determined regional trend. Datasets with high variability contributed less to the inference of the regional trend. Variation among trends within a region along with precision of individual trends determined the variation in regional trend.

We used the following three meta-analysis techniques described by Manly (2001):

- Fisher's method addressed the hypothesis that at least one of the indices showed a significant decline. The test statistic was calculated by $S_{1}=-2 \sum \ln \left(p_{i}\right)$, where $p_{i}$ was the one-tailed $p$ value that tested for a significantly negative regression slope for the $i$ th index.

- Stouffer's method addressed the hypothesis that there was a consensus for a decline supported by the set of indices. Here the individual one-tailed $p$ values were converted to $z$-scores, which under the null hypothesis were distributed as a Normal random variable with mean of zero and a variance of $1 / \sqrt{n}$, where $n$ was the number of datasets. The test statistic was $S_{2}=\bar{z} /(1 / \sqrt{n})$. A version of the Stouffer's method incorporated weighting into the calculation of the test statistic. We used a measure of precision (the inverse of the root mean square error, i.e., the RMSE) as the weight $\left(w_{i}\right)$. The weighted test statistic was $S_{3}=\left(\sum w_{i} z_{i}\right) / \sqrt{\sum w_{i}^{2}}$.

- A weighted standardized slope along with confidence intervals addressed the hypothesis that the datasets showed a significant decline on average. Datasets with the higher precision (inverse of the RMSE) received greater weight than those with lower precision. The calculation of the weighted slope was $\bar{b}_{w}=\sum w_{i} b_{i} / \sum w_{i}$, where $b_{i}$ was the slope for the $i$ th dataset. The standard error was $s e\left(\bar{b}_{w}\right)=\sqrt{\sum w_{i}\left(b_{i}-\bar{b}_{w}\right)^{2} /\left(\sum w_{i}(n-1)\right)}$. The $t$-distribution was used to calculate confidence intervals. 


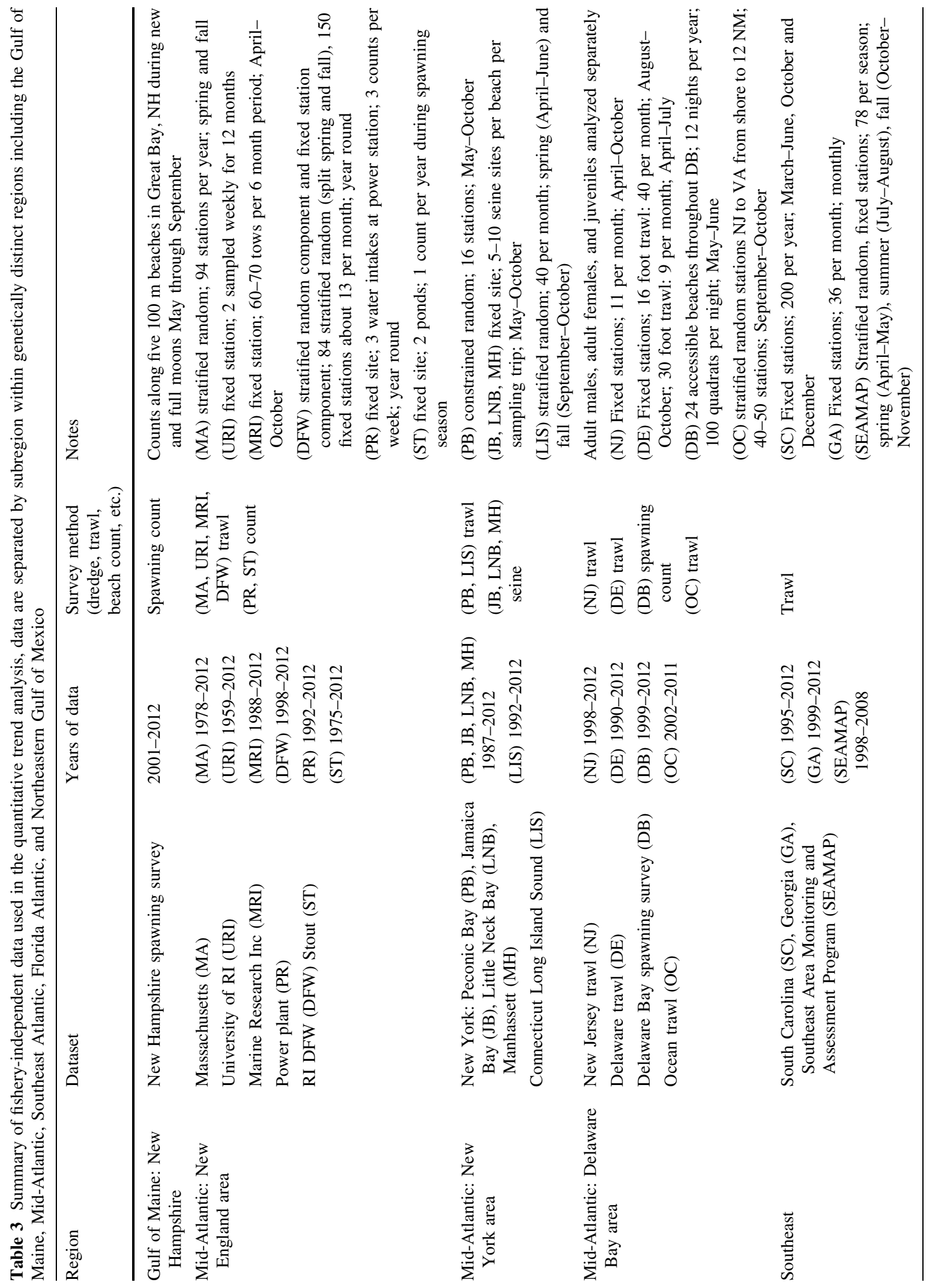


Results indicated that significant declines occurred in at least one dataset in all areas except the Southeast and Florida as evidenced by test S1 (Table 4). Tests S2, S3, and weighted slope all indicate that the breadth of declines was highest in the New England area and diminished from the northern to southeastern areas with indications of negative slopes for Florida Atlantic and Northeast Gulf regions (Table 4; Fig. 4). The uncertainty in the Florida Atlantic region was high, in part, because of the variation in trends among a small number of available datasets (Fig. 4). Although the inference for Florida Atlantic region suggested no significant decline in the horseshoe crab population, the datasets from Jacksonville indicated an embayment-specific decline.

For those regions or sub-regions with a negative trend (i.e., Gulf of Maine (NH), New England area, New York area, Northeast Gulf region), population reduction over 40 years can be projected assuming a continuation of the current linear trends. The formula used for this projection was

\section{Percent projected population change $=\left((1+\lambda)^{40}-1\right) \times 100$,}

where $\lambda$ denoted the trend and 40 years coincided with three generations based on age-structured population models (Sweka et al. 2007). Continuation of these negative trends over 40 years would result in projected population reductions of $100 \%$ in the Gulf of Maine (NH), 92\% in New England, $11 \%$ in New York, $55 \%$ in Florida Atlantic, and 32\% in Northeast Gulf of México. Although not accounting for carrying capacity limits to population growth, projections indicate population increases in the Delaware Bay of $116 \%$ and the Southeast region of $218 \%$ over 40 years.

Population viability analyses

Several efforts have occurred to develop horseshoe crab population models useful for assessing population viability (Gibson and Olszewski 2001; Grady and Valiela 2006; Davis et al. 2006; Sweka et al. 2007; McGowan et al. 2011b; Smith et al. 2013). Modeling studies have focused on horseshoe crab populations in Rhode Island (Gibson and Olszewski 2001), Cape Cod (Grady and Valiela 2006), and Delaware Bay (Davis et al. 2006; Sweka et al. 2007; McGowan et al. 2011b; Smith et al. 2013). All analyses concluded that while high harvest results in population depletion, some 


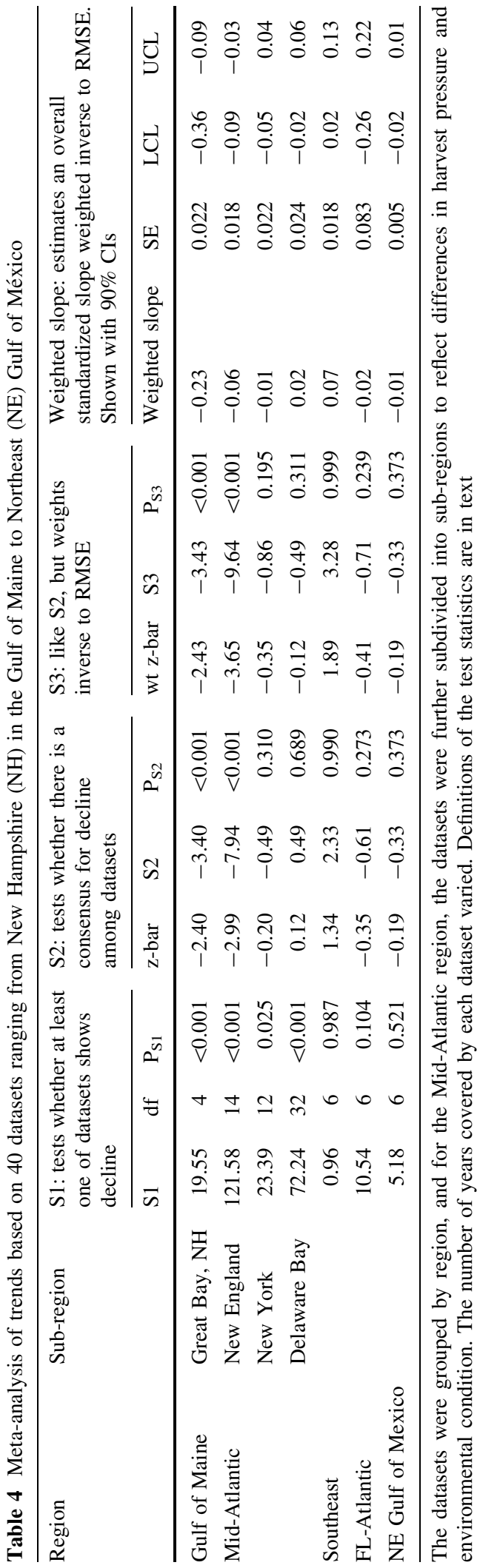

levels of reduced harvest can be compatible with maintenance of a viable population. Gibson and Olszweski (2001) and Davis et al. (2006) used production models to examine conditions for population recovery in Rhode Island and Delaware Bay that had been depleted by overfishing. Gibson and Olszweski (2001) estimated intrinsic growth rate of 0.5 (finite rate of 1.6) for the population in Rhode Island and concluded that recovery would take 10 years of no harvest and 20 years under harvest well below recent levels. Davis et al. (2006) concluded that the Delaware Bay population had been overfished and projected that recovery could occur within 4 years, but likely would take longer than 15 years. Grady and Valiela (2006) and Sweka et al. (2007) used life-history structured models to examine population dynamics of populations in Cape Cod embayments and Delaware Bay, respectively. Sensitivity analyses indicated that population growth was most sensitive to variation in early life stage and juvenile survival. The generation time according to the age-structured population model (Sweka et al. 2007) model is 13.7 years. The modeling by Grady and Valiela (2006) suggested that seasonal closures along with low levels of harvest are required for sustainability. Sweka et al. (2007) examined the role of density-dependent egg mortality on population abundance under different harvest levels, and consistent with previous analyses, identified sustainable harvest levels that allowed for population growth. The Sweka et al. (2007) model became the basis for predictive modeling to support adaptive management of horseshoe crab in Delaware Bay (Smith et al. 2013; McGowan et al. 2015; Millard et al. 2015).

\section{Conservation approaches}

Atlantic states marine fisheries commission management plan

As described above, horseshoe crabs are harvested primarily for bait in commercial fisheries and collection of their blood for use in the biomedical industry. The ASMFC regulates harvest along the Atlantic coast. The mission of the ASMFC is to promote "better utilization of the fisheries, marine, shell and anadromous, of the Atlantic seaboard by the development of a joint program for the promotion and 


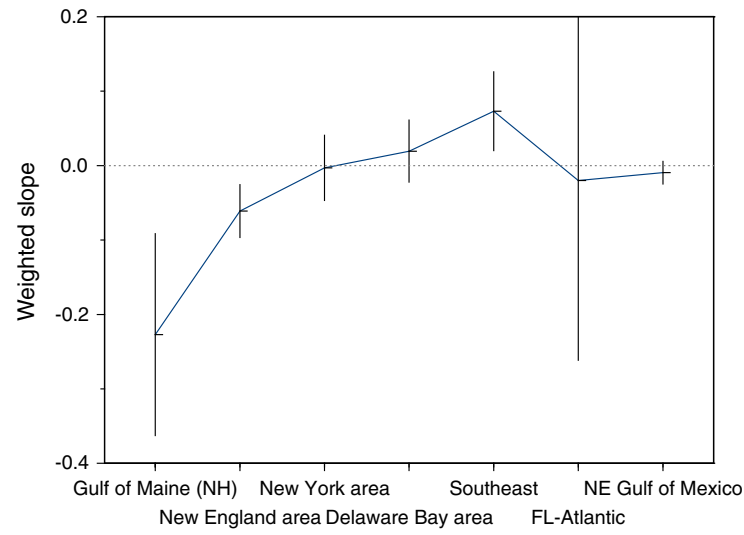

Fig. 4 Weighted slope with $90 \%$ confidence bars from meta analyses of multiple datasets from New Hampshire $(\mathrm{NH})$ in the Gulf of Maine region to the Northeast (NE) Gulf of México region with time series spanning different years. A weighted slope was an average of dataset-specific slopes weighted inverse to mean square error, which accounts for variability. Regions and areas with regions are described in the text and in Fig. 1. The datasets were grouped and oriented generally north to south on the x-axis. The datasets from Gulf of Maine New Hampshire are from the Great Bay. The New England, New York, and Delaware Bay constitute areas within the Mid-Atlantic region. The Southeast, Florida Atlantic, and Northeast Gulf are separate regions

protection of such fisheries, and by the prevention of physical waste of the fisheries from any cause". The ASMFC serves as the deliberative body that coordinates the conservation and management of the shared near-shore fishery resources for the 15 Atlantic coastal states, as well as the U.S. Fish and Wildlife Service (FWS) and NOAA Fisheries. Each state is responsible for implementing management measures within its jurisdiction in a manner consistent with the regulations outlined in the ASMFC Interstate Fisheries Management Plan (IFMP; ASMFC 1998) and associated addendums, with the caveat that the States can always implement more conservative measures should they desire.

A management board exists for each of the species under the jurisdiction of the ASMFC and is responsible for developing and implementing a management plan for the species. The management board relies on input from technical committees and an advisory panel. A Horseshoe Crab Technical Committee and a Delaware Bay Ecosystem Technical Committee were formed to provide scientific advice to the Horseshoe Crab Management Board. These technical committees are staffed by state biologists, as well as representatives from NOAA Fisheries, USFWS, and members of academia. They assess and interpret relevant data on horseshoe crabs and associated shorebirds, analyze the likely impacts of possible management actions, and make science-based recommendations to the Management Board.

The ASMFC Horseshoe Crab Management Board developed an IFMP for horseshoe crabs in October 1998 (ASMFC 1998), and seven Addenda have been approved since then to reflect improved understanding of exploitation and population dynamics. The horseshoe crab management plan is relatively unique in that it explicitly incorporates objectives for both a sustainable fishery as well as continued function in the trophic ecology of coastal systems, i.e. use by migratory shorebirds and sea turtles (McGowan et al. 2015). The migratory shorebirds that utilize Delaware Bay as a critical stopover includes the federally threatened red knot, Calidris canutus rufa (FWS-R5-ES-2013-0097, http://www.fws.gov/northeast/redknot/pdf/2014_ 28338_fedregisterfinalrule.pdf). Since 2000, harvest of horseshoe crabs has been managed by a quota system for each Atlantic coast state, based on an across-the-board reduction from an established reference period landing (Table 5).

Harvest quotas govern state-specific harvest regulations (Table 5), although individual states have the option of imposing more conservative measures. The Delaware Bay states have had the most complex regulatory history because of the link between horseshoe crabs and shorebirds within Delaware Bay. Since the adoption of ASMFC IFMP in 1998, a series of increasingly conservative sex-specific harvest quotas and seasonal restrictions were implemented in the four states surrounding Delaware Bay, i.e. Delaware, New Jersey, Maryland and Virginia. New Jersey instituted a complete moratorium on harvesting horseshoe crabs from state waters in 2006, and this ban remains in effect. In February 2012, the ASMFC Horseshoe Crab Management Board approved Addendum VII, which provides for managing harvest of Delaware Bay-origin animals via an Adaptive Resource Management (ARM) framework, wherein annual harvest is derived via a suite of multispecies models and an optimization process which takes into account many biological variables, including the status of the horseshoe crab population and the red knot population (ASMFC 2009; McGowan et al. 2011b, 2015). The ARM framework also defines monitoring programs and procedures to 
update the modeling structure and parameterization including uncertainty. The ARM framework provides managers a recommended harvest which seeks to maximize harvest numbers with the constraint that harvest occurs only after achieving accepted thresholds for the red knot and horseshoe crab populations. The harvest alternatives from which the ARM framework determines an optimum range from no harvest whatsoever to a maximum of 420,000 males and 210,000 females. The total harvest of horseshoe crab from Delaware Bay, prescribed by the ARM framework, is allocated among the four Bay-area States via an algorithm based in part on the likely proportion of each state's catch being animals of Delaware Bay origin.

In an effort to further ensure a viable horseshoe crab population in the mid-Atlantic region, NOAA Fisheries established a $3885 \mathrm{~km}^{2}$ no-take zone in Federal waters outside the mouth of Delaware Bay (Fig. 5), an area is known to have large concentrations of horseshoe crabs (Botton and Haskins 1984; Botton and Ropes 1987). Harvest or possession of horseshoe crabs aboard vessels within the Carl N. Shuster Jr.
Horseshoe Crab Reserve is prohibited. An exempted fishing permit for the capture of horseshoe crabs in the Reserve for biomedical purposes was issued annually to Limuli Laboratories, Inc. by NOAA Fisheries between 2001 and 2013. The permit allowed for the capture of up to 10,000 animals annually and required the permittee to collect demographic and morphometric data on the collected animals.

\section{Northeast Gulf of Mexico region}

Relatively low abundance of horseshoe crabs limits their commercial harvest in the Gulf of Mexico. Currently, horseshoe crab harvest in the Gulf of Mexico is not addressed by the Gulf States Marine Fisheries Commission (GSMFC), although they have discussed the need for regulations. Florida's regulations, which apply to both the Atlantic and Gulf sides of the state, regulate harvest of horseshoe crabs for commercial use (bait, biomedical and marine-life). Management of bait harvest on the west coast of Florida involves the same minor (i.e., de minimis) regulations as those on the east coast but without a bait

Table 5 State-specific bait harvest quotas based on Addendum IV of the Atlantic States Marine Fisheries Commission's (ASMFC) Fishery Management Plan for horseshoe crabs

\begin{tabular}{llll}
\hline State & Landings in 1998 & ASMFC harvest quota enacted 2006 & Avg landings (2008-2012) \\
\hline Maine & 13,500 & 13,500 & 0 \\
New Hampshire & 350 & 350 & 8 \\
Massachusetts & 440,503 & $330,377^{\mathrm{a}}$ & 86,197 \\
Rhode Island & 26,053 & $26,053^{\mathrm{a}}$ & 26,618 \\
Connecticut & 64,919 & 48,689 & 142,380 \\
New York & 488,362 & $366,272^{\mathrm{a}}$ & 0 \\
New Jersey & 604,049 & $100,000^{\mathrm{a}, \mathrm{b}}$ & 0 \\
Pennsylvania & 0 & 0 & 92,488 \\
Delaware & 482,401 & $100,000^{\mathrm{b}}$ & 166,083 \\
Maryland & 613,225 & $170,653^{\mathrm{b}}$ & 141,544 \\
Virginia & 203,326 & $152,495^{\mathrm{b}}$ & 23,826 \\
North Carolina & 24,036 & 24,036 & 0 \\
South Carolina & 0 & 0 & 0 \\
Georgia & 29,312 & 29,312 & 209 \\
Florida & 9455 & 9455 & 695,096 \\
Coastwide & $2,999,491$ & $1,371,192$ & 26
\end{tabular}

Addendum IV was enacted in 2006. Average reported landings (animals) are shown for 2008-2012

${ }^{\text {a }}$ States have set a more conservative quota

b New adaptive management quota set annually 
Fig. 5 The Carl N. Shuster Jr. Horseshoe Crab Reserve (gray area) off the mouth of Delaware Bay, which is a marine protected area where harvest of horseshoe crabs is prohibited. Map was reproduced from Walls et al. (2002)

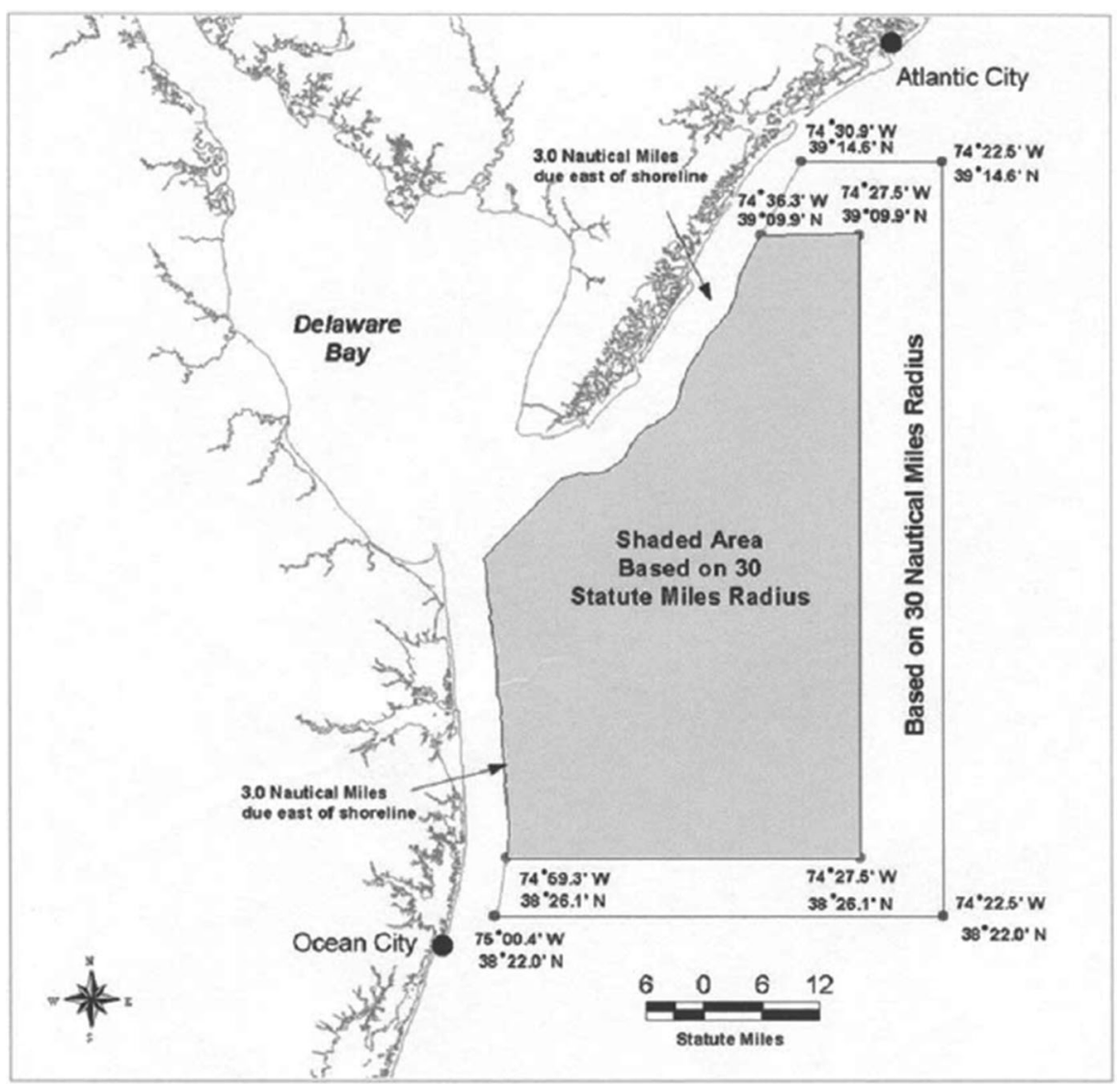

harvest quota. There is no biomedical harvest in Florida at this time. The "marine life" fishery is managed via daily bag limits (100/person/day) and hand harvest, but there is no cap on the total number that can be harvested. No other Gulf state regulates the harvest of horseshoe crabs.

\section{Yucatán region}

In 1994, horseshoe crabs in México were assigned the status "en peligro de extinción" (literally, "in danger of extinction"), the highest risk category for extant species in the Mexican Official Standard for Mexican species at risk (SEDESOL 1994; SEMARNAT 2010). Under that Standard, a species is assigned such status if "its distribution or population size have drastically decreased, putting its biological viability at risk throughout its range, as a result of the destruction or drastic modification of its habitat, severe restriction of its distribution, over-exploitation, disease, and predation, among other causes" (SEDESOL 1994;
SEMARNAT 2010). As for all species in the "en peligro de extinción" or "amenazada" (i.e., threatened) protection categories, harvesting of horseshoe crabs is forbidden by federal law in México, unless it is proven that: a) harvesting quotas are below levels that allow the natural replenishment of the harvested wild population, or b) they are the result of controlled reproduction, in the case of captive organisms, or c) when the use of parts or tissues is involved, it will not negatively affect the population or modify the specimens' life cycle, or d) when the collection of derivatives from specimens is involved, loss of these derivatives or the procedure used to collect them will not permanently harm specimens (Diario Oficial de la Federación 2014b). Also, possession of harvested specimens or their parts and derivatives from wild populations must be accompanied by proof that controlled reproduction programs are in place to replenish these populations. In case harvested specimens come from captive populations, controlled reproduction of specimens in these populations must 
support governmental programs aimed at replenishing wild populations (Diario Oficial de la Federación 2014b). Currently, the legal status of horseshoe crab in México (en peligro de extinción) prohibits legal harvest, which does not preclude the possibility of illegal trade for bait.

\section{Alternative bait strategies}

Innovative efforts to reduce the quantity of horseshoe crabs required to meet the demand for the bait industry have produced some gains. Since 1999, the fishing industry began to adopt the use of bait bags, wherein smaller portions of horseshoe crabs could be used as bait in a single conch pot, as opposed to a whole animal. This practice has expanded along the coast and resulted in a more efficient use of horseshoe crabs as bait for the conch fishery (Millard et al. 2015).

An alternative bait, which chemically mimics the horseshoe crab, has been developed and was commercially marketed for the first time in 2013 (Wakefield 2013). Preparation of the bait by individuals is also possible via a published recipe. The product is a result of years of research by a team of researchers from the University of Delaware (Ferrari and Targett 2003). While the product contains horseshoe crab tissue in its formulation, the amount is small enough such that widespread use of the artificial bait would significantly reduce bait harvest. However, studies to determine the efficacy and marketability of the artificial bait have not yet been finalized (Eyler et al. 2015).

\section{Propagation and release}

Propagation has been proposed as a conservation action to restore depleted populations or substitute animals for marine-life collection (Tsuchiya 2009; Carmichael and Brush 2012; Landau et al. 2015). Carmichael and Brush (2012) reviewed the effect of propagation practices on growth and survival of captive-reared animals. They noted a paucity of documented research on propagation techniques and identified specific information gaps. The potential for propagation as a conservation action is restrained by high mortality of horseshoe crabs kept in captivity for more than six months, which has been commonly observed among published studies (Carmichael and Brush 2012), and unknown post-release survival of captive-reared animals. The state of the science for propagation and release is focused currently on rearing techniques, but ultimately the responsible use for restoration should follow guidelines developed for enhancing marine stocks (cf Blankenship and Leber 1995).

Law enforcement

Increased prices and reduced availability of horseshoe crabs in the U.S. bait trade has motivated dealers to import Asian horseshoe crab species (C. rotundicauda, T. gigas, T. tridentatus) for use as bait in the domestic conch and eel fisheries (Botton et al. 2015). These importations are viewed as a significant threat to native Limulus populations due to possible introductions of harmful parasites and pathogens into U.S. waters. Also, C. rotundicauda are known to accumulate tetrodotoxin, a potentially lethal neurotoxin, and concerns that eel and whelk may accumulate this toxin argue against continued importation of Asian species. For these reasons, the ASMFC approved a resolution to ban the import and use of Asian horseshoe crabs as bait (ASMFC Resolution 13-01 http://www.asmfc. org/uploads/file/pr08HSC_AsianCrabResolution.

pdf). However, the ASMFC resolution is not enforceable. The applicable Federal statute (Lacey Act) presently applies to various taxa, including crustaceans, but not to chelicerates. Additional legislation at the Federal level would be required to designate non-native species, such as Asian horseshoe crabs, as invasive or injurious and prohibit their importation.

Increased prices for horseshoe crabs in the bait market may also be responsible for increased incidences of illegal harvest. Charges were brought in two cases of illegal harvest in New York waters in the summer of 2013. The amount of illegal harvest in the mid-Atlantic region is unknown, although awareness by enforcement authorities is increasing (cf NY Times, July 4 2013, p. A1).

\section{Habitat-based conservation actions}

The creation, restoration, or protection of beach or nearshore habitat specifically for the benefit of horseshoe crab populations is not common throughout the Atlantic coast. The beach replenishment or fill activities, which occur in several states (e.g. Delaware, New Jersey, Maryland, Massachusetts), are justified 
and pursued protection of communities and infrastructure, particularly for beaches damaged by storm erosion. As an incidental benefit, these projects also augment horseshoe crab spawning habitat. The Maryland Department of Natural Resources replenished Skimmer Island near Ocean City using dredge spoils, which nearly doubled the available horseshoe crab spawning habitat (Steve Doctor, Maryland Department of Natural Resources, personal communication). Jackson and Nordstrom (2009) outline a management framework based on general principles for conserving shoreline habitat for horseshoe crabs.

Current management programs do not specifically focus on horseshoe crabs or their habitats in the U.S. Gulf of Mexico or México. However, significant portions of coastal habitats in the Yucatán Peninsula, including coastal lagoons where horseshoe crabs are common and have been reported to reproduce, are under the jurisdiction of both federal and state protected areas with different legal regimes. Although none of the management programs of these protected areas include actions to protect horseshoe crabs, protected area administrations pay particular attention and devote considerable efforts to the monitoring and preservation of mangrove forests. This monitoring effort is the result of an amendment to the Federal Law for Wildlife passed in 2007 that forbids and severely punishes any activities that may negatively affect mangrove forests and related ecosystems in Mexico (Diario Oficial de la Federación 2014a, b). In fact, 76.3, 90.4 and 79\% of mangrove forests in Yucatán, Campeche and Quintana Roo, respectively, have been estimated to be within the limits of a federal or state protected area (CONABIO 2009), and hence, these ecosystems are subject to management programs. Given that all protected coastal lagoons in the Yucatán Peninsula harbor mangrove forests, it can be said that, in México at least, a legal framework is in place and actions are being taken that incidentally conserve critical habitats for horseshoe crabs.

\section{Summary of conservation status}

Population reductions in horseshoe crabs have occurred over much of its range, but in particular within the Mid-Atlantic region. Past overharvest is understood to be the cause; however, that has been corrected through active management intervention over much of the range. An assessment of population trend indicates population stability in the Delaware Bay area of the Mid-Atlantic region and population growth in the Southeast region. Population decreases continued in the Great Bay of New Hampshire in the Gulf of Maine region, the New England and New York areas within the Mid-Atlantic region and the Northeast Gulf of Mexico. The assessment of trends in the Florida Atlantic region was highly uncertain with a decreasing population in the Jacksonville area somewhat offset by an increasing population in the Indian River area. On the Florida Gulf of Mexico coast, trends were assessed to be slightly negative. The underlying cause for reductions in Florida is unclear, but there is a concern that harvest for marine life specimens in Florida is unsustainable and remaining threats include mortality due to power plant and habitat loss from shoreline development.

Mexican populations require proper assessment and monitoring, especially in sites where poaching is known to occur. Qualitative opinions by at least one researcher (Gómez-Aguirre 1979, 1980, 1983, 1985, 1993) through frequent visits to the Laguna de Términos area between the 1960s and 1990s, indicated a pronounced decline in that locality. However, the legal status of horseshoe crabs in México provides the nation's highest conservation protection.

The near-term threat to horseshoe crabs is unsustainable harvest for whichever purpose: bait, biomedical, or marine life. Declines occurring since the $1980^{\prime} \mathrm{s}$ in the Mid-Atlantic region in particular are understood to have been caused by overharvesting for bait. Harvest regulations, which were focused on bait harvest and instituted over the past 15 years, have shown signs of reversing population reductions in some areas. Nevertheless, population declines within some sub-regions continue indicating that current harvest levels in those areas might be unsustainable. In addition, the long-term and emerging threat to horseshoe crabs is habitat loss. While current habitat appears sufficient to support robust populations, habitat conditions could change as coastlines are developed and impacted by climate change and sea level rise. Thus, horseshoe crab conservation status is vulnerable at the species level with potential for higher risk status at the regional and sub-regional levels, particularly the Yucatán Peninsula region, New England area of the Mid-Atlantic region, and Great Bay estuary within the Gulf of Maine region. 
Horseshoe crab geographic range is too vast to warrant a threatened risk category at the species level based on geographic range. However, the risk is elevated within certain regions depending on the coastline available for spawning and degree of fragmentation (or the number of spawning populations) and continuation of decline or extreme fluctuation of population size. For the Gulf of Maine region, spawning habitat is limited and fragmented. Breeding appears to have stopped at some historical locations. For the Florida Atlantic region, the degree of fragmentation is unclear, but embayments are subject to decline due to local exploitation from marine-life harvest, impingement at power plants, and shoreline development. For the Yucatán Peninsula, the coastline habitat in México is fragmented, and thought to be at risk of continued decline. Thus, spawning populations appear to be at risk in the Gulf of Maine, Florida Atlantic, and Yucatán Peninsula regions due to limited and fragmented spawning habitat, which are subject to local threats of habitat loss and exploitation.

Population viability analyses indicate that current management in Delaware Bay area of the MidAtlantic is consistent with a viable population, but also shows that the New England area must restrict harvest further to avoid a risk of endangerment and potential loss at the embayment level. Extending quantitative analyses into other regions beyond the Delaware Bay and Cape Cod should receive high priority in research and assessment.

\section{Conclusions}

The outcome of this assessment is that the American horseshoe crab species is vulnerable to local extinction and that the degree and extent of the risk vary among and within the genetically-defined regions.

- Gulf of Maine region The geographic range in the Gulf of Maine region is restricted and potentially fragmented. Spawning appears to no longer occur in some historical locations, indicating a past decline; however, declines may not continue beyond surveyed beaches.

- Mid-Atlantic region The populations of horseshoe crabs in the Mid-Atlantic region are stable in the Delaware Bay area, but indicate continuing declines in New England. Causes of continuing declines are understood to be over-harvest, and there are regulatory controls in place. Nevertheless, a concern is warranted for the New England area until it is apparent that regulatory controls are adequate to reverse the continuing declines.

- Southeast region The populations of horseshoe crabs in the Southeast region appear stable or increasing.

- Florida Atlantic region The populations of horseshoe crabs in the Florida Atlantic region show mixed trends among areas and degree of demographic fragmentation among local populations is unclear. However, continuing population reductions at the embayment level have poorly understood causes, although marine life collection may be a contributing factor. A concern is warranted for the Florida Atlantic region until threats are fully understood and managed.

- Northeast Gulf of México region Projected population reductions in the Northeast Gulf of México over three generations do not warrant a high concern. However, causes of population trends in this region are poorly understood, and currently there is no active management of horseshoe crabs within the Northeast Gulf of México. Active management and monitoring should be a priority within the Northeast Gulf of México region, especially outside of Florida where data are deficient.

- Yucatán Peninsula region The legal status of horseshoe crabs within México provides the highest conservation protection. Habitat is limited and fragmented, and populations in México are geographically isolated from other regions. Thus, a concern is warranted for the Yucatán Peninsula region until sufficient data can confirm population stability.

Acknowledgements We thank the IUCN Horseshoe Crab Species Specialist Group (SSG) for initiating the rangewide assessment and Mark Botton and Paul Shin, SSG co-chairs, for their support and guidance. Also, Mark Botton, Paul Shin, Ruth Carmichael, Kevin Laurie, John Tanacredi, Thomas Novitsky, Ding Jeak Ling, Bow Ho, Vinayangan Dharmarajah, Conor McGowan, and two anonymous reviewers provided helpful review comments which improved the paper. Any use of trade, product, or firm names is for descriptive purposes only and does not imply endorsement by the U.S. Government.

Open Access This article is distributed under the terms of the Creative Commons Attribution 4.0 International License (http:// 
creativecommons.org/licenses/by/4.0/), which permits unrestricted use, distribution, and reproduction in any medium, provided you give appropriate credit to the original author(s) and the source, provide a link to the Creative Commons license, and indicate if changes were made.

\section{References}

Álvarez-Añorve LI, Astivia-Anievas MR, Godinez-Álvarez HO, Gómez-Aguirre SH, González-Uribe JF, OchoterenaBooth H, Rodríguez-Lucatero A, Salas-García M, Sapién Silva RE (1989) Informe Técnico de Biología de Campo: Demografía de Limulus polyphemus L. III; Estudio de la Población de Isla Aguada, Laguna de Términos, Campeche, Méx. Facultad de Ciencias. Universidad Nacional Autónoma de México, México

Anderson LI, Shuster CN Jr (2003) Throughout geologic time: where have they lived? In: Shuster CN Jr, Barlow RB, Brockmann HJ (eds) The American horseshoe crab. Harvard University Press, Cambridge, pp 189-223

Anderson RL, Watson WH, Chabot CC (2013) Sublethal behavioral and physiological effects of the biomedical bleeding process on the American horseshoe crab, Limulus polyphemus. Biol Bull 225:137-151

Arkema KK, Guannel G, Verutes G, Wood SA, Guerry A, Ruckelshaus M, Kareiva P, Lacayo M, Silver JM (2013) Coastal habitats shield people and property from sea-level rise and storms. Nat Clim Change 3:913-918. doi:10.1038/ NCLIMATE1944

Atlantic Marine States Fisheries Commission (ASMFC) (1998) Interstate fishery management plan for horseshoe crab. Atlantic Marine States Fisheries Commission, Fishery Management Report No. 32. Arlington. http://www.asmfc. org/uploads/file/hscFMP.pdf. Accessed 3 Feb 2016

Atlantic Marine States Fisheries Commission (ASMFC) (2009) Horseshoe crab stock assessment report. Atlantic States Marine Fisheries Commission, Arlington. http://www. asmfc.org/uploads/file/

2009HorseshoeCrabStockAssessmentReport.pdf. Accessed 3 Feb 2016

Atlantic Marine States Fisheries Commission (ASMFC) (2013) Review of the Atlantic States Marine Fisheries Commission Fishery management plan for Horseshoe Crab (Limulus polyphemus). Atlantic States Marine Fisheries Commission, Arlington. http://www.asmfc.org/uploads/ file/hscFMPReview2013.pdf. Accessed 3 Feb 2016

Baptist JP, Smith OR, Ropes JW (1957) Migrations of the horseshoe crab, Limulus polyphemus, in Plum Island Sound, Massachusetts. U.S. Fish and Wildlife Service, Special Scientific Report-Fisheries No. 220. Washington

Barba-Macias E, Castillo-Blancarte A, Coreno-Vazquez M, Castellanos-Albores MT, Cu-Srmiento IN, GamboaRomero HA, Gomez-Aguirre S, Hurtado-Gonzalez C, Ochoterena-Booth H, Sapién Silva RE, Velazco-Velazco AM (1988) Informe Tecnico, Biologia de Campo: Demografia de Limulus polyphenus L. II; Sus areas de arribazon en los Litorales de Campeche, Mex. Facultad de Ciencias, Universidad Nacional Autonoma de Mexico, Mexico
Barlow RB, Powers MK, Howard H, Kass L (1986) Migration of Limulus for mating: relation to lunar phase, tide height, and sunlight. Biol Bull 171:310-329

Beekey MA, Mattei JH (2009) What long-term mark/recapture studies reveal about horseshoe crab population dynamics in Long Island Sound. In: Proceedings of the 2008 biennial long Island sound research conference, Connecticut College, Groton. http://lisfoundation.org/downloads/lisrc_ proceedings2008.pdf. Accessed 3 Feb 2016

Beekey MA, Mattei JH (2015) The mismanagement of Limulus polyphemus in Long Island Sound, U.S.A.: what are the characteristics of a population in decline. In: Carmichael RH, Botton ML, Shin PKS, Cheung SG (eds) Changing global perspectives on horseshoe crab biology, conservation and management. Springer, New York, pp 433-461

Beekey MA, Mattei JH, Pierce BJ (2013) Horseshoe crab eggs: A rare resource for predators in Long Island Sound. J Exp Mar Biol Ecol 439:152-159

Berkson J, Shuster CN Jr (1999) The horseshoe crab: the battle for a true multiple-use resource. Fisheries 24:6-10

Blankenship HL, Leber KM (1995) A responsible approach to marine stock enhancement. Am Fish Soc Symp 15:167-175

Błażejowski B (2015) The oldest species of the genus. In: Carmichael RH, Botton ML, Shin PKS, Cheung SG (eds) Changing global perspectives on horseshoe crab biology, conservation and management. Springer, New York, pp 3-14

Bonilla-Gonzalez E, Espinoza-Garcia AC, Fernandex-Buces N, Flores-Moran M, Gomez-Aguirre S, de la Torre A, FloresPalacios MV, Llaca-Garcia VA, Martinez-Vazquez ML, Ochoterena-Booth H, Pastrana-Martinez A, Pelcastre-Villafuerte L, Perez-Vertti-Rojas JC, Rodriguez-Palacios CA, Sapién Silva RE (1986) Informe Tecnico, Biologia de Campo: Introduccion a la Demografia de Limulus polyphemus L. Facultad de Ciencias. Universidad Nacional Autonoma de Mexico, Mexico

Botton ML (2009) The ecological importance of horseshoe crabs in estuarine and coastal communities: a review and speculative summary. In: Tanacredi JT, Botton ML, Smith DR (eds) Biology and conservation of horseshoe crabs. Springer, New York, pp 45-64

Botton ML, Haskins HH (1984) Distribution and feeding of the horseshoe crab, Limulus polyphemus, on the continental shelf off New Jersey. Fish Bull 82:383-389

Botton ML, Itow T (2009) The effects of water quality on horseshoe crab embryos and larvae. In. In: Tanacredi JT, Botton ML, Smith DR (eds) Biology and conservation of horseshoe crabs. Springer, New York, pp 439-454

Botton ML, Loveland RE (1989) Reproductive risk: high mortality associated with spawning by horseshoe crabs (Limulus polyphemus) in Delaware Bay, USA. Mar Biol 101:143-151

Botton ML, Loveland RE (2003) Abundance and dispersal potential of horseshoe crab Limulus polyphemus larvae in the Delaware estuary. Estuaries 26:1472-1479

Botton ML, Ropes JW (1987) Populations of horseshoe crabs Limulus polyphemus, on the northwest Atlantic continental shelf. Fish Bull 85:805-812

Botton ML, Ropes JW (1988) An indirect method for estimating longevity of the horseshoe crab (Limulus polyphemus) 
based on epifaunal slipper shells (Crepidula fornicate). J Shellfish Res 7:407-412

Botton ML, Ropes JW (1989) Feeding ecology of horseshoe crabs on the continental shelf, New Jersey to North Carolina. Bull Mar Sci 45:637-647

Botton ML, Loveland RE, Jacobsen TR (1988) Beach erosion and geochemical factors: influence on spawning success of horseshoe crabs Limulus polyphemus in Delaware Bay. Mar Biol 99:325-332

Botton ML, Loveland RE, Jacobsen TR (1992) Overwintering by trilobite larvae of the horseshoe crab Limulus polyphe$m u s$ on a sandy beach of Delaware Bay (New Jersey, USA). Mar Ecol Prog Ser 88:289-292

Botton ML, Loveland RE, Jacobsen TR (1994) Site selection by migratory shorebirds in Delaware Bay, and its relationship to beach characteristics and abundance of horseshoe crab Limulus polyphemus eggs. Auk 111:605-616

Botton ML, Harrington B, Tsipoura N, Mizrahi D (2003) Synchronies in migration: shorebirds, horseshoe crabs, and Delaware Bay. In: Shuster CN Jr, Barlow RB, Brockmann HJ (eds) The American horseshoe crab. Harvard University Press, Cambridge, pp 5-32

Botton ML, Tankersley RA, Loveland RE (2010) Developmental ecology of the American horseshoe crab Limulus polyphemus. Curr Zool 56:550-562

Botton ML, Carmichael RH, Shin PKS, Cheung SG (2015) Emerging issues in horseshoe crab conservation: a perspective from the IUCN species specialist group. In: Carmichael RH, Botton ML, Shin PKS, Cheung SG (eds) Changing global perspectives on horseshoe crab biology, conservation and management. Springer, New York, pp 369-381

Britton JC, Morton B (1989) Shore Ecology of the Gulf of México. University of Texas Press, Austin

Brockmann HJ (1990) Mating behavior of horseshoe crabs Limulus polyphemus. Behaviour 114:206-220

Brockmann HJ (1996) Satellite male groups in horseshoe crabs, Limulus polyphemus. Ethology 102:1-21

Brockmann HJ (2002) An experimental approach to altering mating tactics in male horseshoe crabs Limulus polyphemus. Behav Ecol 13:232-238

Brockmann HJ (2003a) Male competition and satellite behavior. In: Shuster CN Jr, Barlow RB, Brockmann HJ (eds) The American horseshoe crab. Harvard University Press, Cambridge, pp 50-82

Brockmann HJ (2003b) Nesting behavior: a shoreline phenomenon. In: Shuster CN Jr, Barlow RB, Brockmann HJ (eds) The American horseshoe crab. Harvard University Press, Cambridge, pp 33-49

Brockmann HJ, Johnson SL (2011) A long term study of spawning activity in a Florida Gulf Coast Population of horseshoe crabs (Limulus polyphemus). Estuaries Coasts 34:1049-1067

Brockmann HJ, Penn D (1992) Male mating tactics in the horseshoe crab Limulus polyphemus. Anim Behav 44:653-665

Brockmann HJ, Smith MD (2009) Reproductive competition and sexual selection in horseshoe crabs. In: Tanacredi JT, Botton ML, Smith DR (eds) Biology and conservation of horseshoe crabs. Springer, New York, pp 199-221
Brockmann HJ, Colson T, Potts W (1994) Sperm competition in horseshoe crabs Limulus polyphemus. Behav Ecol Sociobiol 35:153-160

Brockmann HJ, Nguyen C, Potts W (2000) Paternity in horseshoe crabs when spawning in multiple-male groups. Anim Behav 60:837-849

Brockmann HJ, Black T, King TL (2015) Florida horseshoe crabs: populations, genetics and the marine-life harvest. In: Carmichael RH, Botton ML, Shin PKS, Cheung SG (eds) Changing global perspectives on horseshoe crab biology, conservation and management. Springer, New York, pp 97-127

Brousseau LJ, Sclafani M, Smith DR (2004) Acoustic-tracking and radio tracking of horseshoe crabs to assess spawning behavior and subtidal habitat use in Delaware Bay. N Am J Fish Manage 24:1376-1384

Brusca RC, Brusca GJ (2003) Invertebrates. Sinauer Associates, Sunderland

Butler CA (2012) Estimation of survival of the Atlantic horseshoe crab, Limulus polyphemus, by analysis of mark-recapture data with tag loss. MS thesis, Auburn University

Carmichael RH, Brush E (2012) Three decades of horseshoe crab rearing: a review of conditions for captive growth and survival. Rev Aquacult 4:32-43

Carmichael RH, Rutecki D, Valiela I (2003) Abundance and population structure of the Atlantic horseshoe crab Limulus polyphemus in Pleasant Bay, Cape Cod. Mar Ecol Prog Ser 246:225-239

Carmichael RH, Rutecki D, Annett B, Gaines E, Valiela I (2004) Position of horseshoe crabs in estuarine food webs: $\mathrm{N}$ and $\mathrm{C}$ stable isotopic study of foraging ranges and diet composition. J Exp Mar Biol Ecol 299:231-253

Carmichael RH, Gaines E, Sheller Z, Tong A, Clapp A, Valiela I (2009) Diet composition of juvenile horseshoe crabs: implications for growth and survival of natural and cultured stocks. In: Tanacredi JT, Botton ML, Smith DR (eds) Biology and conservation of horseshoe crabs. Springer, New York, pp 521-534

Cary LR (1906) A contribution to the fauna of the coast of Louisiana. Gulf Biol Stn Cameron LA 6:50-59

Chabot CC, Watson WH III (2010) Circatidal rhythms of locomotion in the American horseshoe crab Limulus polyphemus: underlying mechanisms and cues that influence them. Curr Zool 56:499-517

Chabot CC, Skinner SJ, Watson WH III (2008) Rhythms of locomotion expressed by Limulus polyphemus, the American horseshoe crab: I. synchronization by artificial tides. Biol Bull 215:34-45

Chabot CC, Yelle JF, O'Donnell CB, Watson WH III (2011) The effects of water pressure, temperature, and current cycles on circatidal rhythms expressed by the American horseshoe crab, Limulus polyphemus. Mar Freshw Behav Physiol 44:43-60

Chávez H, Muñoz-Padilla F (1975) Nota sobre Xiphosura polyphemus (Ph. Arth-ropoda, $\mathrm{Cl}$. Merostomata) en aguas mexicanas. Rev Soc Mex Hist Nat 36:365-372

Cheng H, Chabot CC, Watson WH III (2015) The life history cycle of Limulus polyphemus in the Great Bay Estuary, New Hampshire USA. In: Carmichael RH, Botton ML, Shin PKS, Cheung SG (eds) Changing global perspectives 
on biology, conservation, and management of horseshoe crabs. Springer, New York, pp 237-253

Cheng H, Chabot CC, Watson WH III (2016) Influence of environmental factors on spawning of the American horseshoe crab (Limulus polyphemus) in the Great Bay Estuary, New Hampshire, USA. Estuaries Coasts 39:1142-1153

Clark K, Niles LJ (1993) Abundance and distribution of migrant shorebirds in Delaware Bay. Condor 95:694-705

Cohen JA, Brockmann HJ (1983) Breeding activity and mate selection in the horseshoe crab Limulus polyphemus. Bull Mar Sci 33:274-281

CONABIO (2009) Manglares de México: Extensión y distribución, 2nd edn. Comisión Nacional para el Conocimiento y Uso de la Biodiversidad. México, México City

Cuevas-Jiménez A, Euán-Ávila J (2009) Morphodynamics of carbonate beaches in the Yucatán Peninsula. Cienc Mar 35:307-320

Davis ML, Berkson J, Kelly M (2006) A production modeling approach to the assessment of the horseshoe crab (Limulus polyphemus) population in Delaware Bay. Fish Bull 104:215-225

Diario Oficial de la Federación (2014a) Código Penal Federal. Secretaría de Gobernación, México City (issued 14 Mar 2014)

Diario Oficial de la Federación (2014b) Ley General de Vida Silvestre. Secretaría de Gobernación, México City (issued March 19 2014)

Duffy EE, Penn DJ, Botton ML, Brockmann HJ, Loveland RE (2006) Eye and clasper damage influence male mating tactics in the horseshoe crab Limulus polyphemus. J Ethol 24:67-74

Ehlinger GS, Tankersley RA (2003) Larval hatching in the horseshoe crab, Limulus polyphemus: facilitation by environmental cues. J Exp Mar Biol Ecol 292:199-212

Ehlinger GS, Tankersley RA (2004) Survival and development of horseshoe crab Limulus polyphemus embryos and larvae in hypersaline conditions. Biol Bull 206:87-94

Ehlinger GS, Tankersley RA (2007) Reproductive ecology of the American horseshoe crab Limulus polyphemus in the Indian River Lagoon: an overview. Fla Sci 70:449-463

Ehlinger GS, Tankersley RA (2009) Ecology of horseshoe crabs in microtidal lagoons. In: Tanacredi JT, Botton ML, Smith DR (eds) Biology and conservation of horseshoe crabs. Springer, New York, pp 149-162

Ehlinger GS, Tankersley RA, Bush MB (2003) Spatial and temporal patterns of spawning and larval hatching by the horseshoe crab, Limulus polyphemus, in a microtidal coastal lagoon. Estuaries 26:631-640

Estes Jr MG (2015) Analysis of the demographic and environmental dynamics of the American horseshoe crab (Limulus polyphemus) in the North Central Gulf of Mexico under changing land cover/land use and climate conditions. Dissertation, Alabama A\&M University

Estes MG Jr, Carmichael RH, Macdonald PDM, Brady A, McFadyen J (2015) Molts reveal life-history patterns for juvenile American horseshoe crabs in fringe habitats. In: Carmichael RH, Botton ML, Shin PKS, Cheung SG (eds) Changing global perspectives on biology, conservation, and management of horseshoe crabs. Springer, New York, pp 255-278
Eyler S, Michels S, Rootes-Murdy K (2015) Review of the Atlantic States Marine Fisheries Commission fishery management plan for horseshoe crab (Limulus polyphemus). Atlantic States Marine Fisheries Commission, Arlington. http://www.asmfc.org/uploads/file/ 56d76a40hscFMPReview2015.pdf. Accessed 3 Feb 2016

Faurby S, King TL, Obst M, Hallerman EM, Pertoldi C, Funch P (2010) Population dynamics of American horseshoe crabshistoric climatic events and recent demographic pressures. Mol Ecol 19:3088-3100

Ferrari KM, Targett NM (2003) Chemical attractants in horseshoe crab, Limulus polyphemus, eggs: the potential for an artificial bait. J Chem Ecol 29:477-496

French KA (1979) Laboratory culture of embryonic and juvenile Limulus. In: Cohen E (ed) Biomedical applications of the horseshoe crab (Limulidae). Alan R. Liss, New York, pp 61-71

Frings H, Frings M (1953) Notes on invertebrates found at Salisbury Cove, Maine in July 1952. Bull Mt Desert Isl Biol Lab 1953:41

Fulford RS, Haehn RA (2012) An evaluation of Mississippi barrier islands as spawning and nesting habitat for the American horseshoe crab, Limulus polyphemus, with implications for island restoration. Gulf Caribbean Res 24:51-62

Gaines EF, Carmichael RH, Grady SP, Valiela I (2002) Stable isotopic evidence for changing nutritional sources of juvenile horseshoe crabs. Biol Bull 203:228-230

Galtsoff PS (1949) The mystery of the red tide. Sci Mon 68:108-117

Gerhart SD (2007) A review of the biology and management of horseshoe crabs, with emphasis on Florida populations. Fish and Wildlife Research Institute, technical report 12, St. Petersburg

Gibson M, Olszewski S (2001) Stock status of horseshoe crabs in Rhode Island in 2000 with recommendations for management. Rhode Island Division of Fish and Wildlife Research Reference Document 01/01

Gilbert S, Clark KB (1981) Seasonal variation in standing crop of the seagrass Syringodium filiforme and associated macrophytes in the Northern Indian River, Florida. Estuaries 4:223-225

Gómez-Aguirre S (1979) Notas para estudios de población de Limulus polyphemus L. (Xiphosura: Xiphosuridae) en la Isla del Carmen, Campeche (1964-1978). Ann Inst Biol Univ Nat Autón México Ser Zool 50:769-772

Gómez-Aguirre S (1980) Ensayo Demográfico de Limulus polyphemus L. del Sureste del Golfo de México (Arthropoda: Merostomata). Mem Resúm IV Cong Nal Zool, 7-12 Dic 1980. Univ Autón de Baja California, Ensenada, Baja California Norte, México

Gómez-Aguirre S (1983) Limulus polyphemus L. (ArthropodaMerostomata) del Sureste del Golfo de México. Mem VIII Simp Latinoamericano de Oceanografía Biológica, Montevideo, Uruguay

Gómez-Aguirre S (1985) Medidas para la protección de Limulus polyphemus L. (Arthropoda-Merostomata), en los litorales de Yucatán. Mem VIII Cong Nal Zool, Escuela Normal Superior del Estado, Saltillo, Coahuila, México I: 461-469

Gómez-Aguirre S (1993) Cacerolita de Mar (Limulus polyphemus L.) en la Península de Yucatán. In: Salazar Vallejo SI, 
González NE (eds) Biodiversidad Marina y Costera de México. CONABIO-CIQRO, México City, pp 650-659

Grady SP, Valiela I (2006) Stage-structured matrix modeling and suggestions for management of Atlantic horseshoe crab, Limulus polyphemus, populations on Cape Cod, Massachusetts. Estuaries Coasts 29:685-698

Grady SP, Rutecki D, Carmichael R, Valiela I (2001) Age structure of the pleasant bay population of Crepidula fornicata: a possible tool for estimating horseshoe crab age. Biol Bull 201:296-297

Graham LJ, Botton ML, Hata D, Loveland RE, Murphy BR (2009) Prosomal-width-to-weight relationships in American horseshoe crabs (Limulus polyphemus): examining conversion factors used to estimate landings. Fish Bull 107:235-243

Gauvry G (2015) Current horseshoe crab harvesting practices cannot support global demand for TAL/LAL: the pharmaceutical and medical device industries' role in sustainability of horseshoe crabs. In: Carmichael RH, Botton ML, Shin PKS, Cheung SG (eds) Changing global perspectives on horseshoe crab biology, conservation and management. Springer, New York, pp 475-512

Hapke CJ, Gratzmann MG, Himmelstoss EA (2013) Geomorphic and human influence on large-scale coastal change. Geomorphology 199:160-170

Haramis MG, Link WA, Osenton PC, Carter DB, Weber RG, Clark NA, Teece NA, Mizrahi DS (2007) Stable isotope and pen feeding trial studies confirm the value of horseshoe crab Limulus polyphemus eggs to spring migrant shorebirds in Delaware Bay. J Avian Biol 38:367-376

Hata D, Berkson J (2004) Factors affecting horseshoe crab Limulus polyphemus trawl survey design. Trans Am Fish Soc 133:292-299

Hata D, Hallerman E (2008) Report of the 2007 horseshoe crab trawl survey. Report to the ASMSC Horseshoe Crab Technical Committee (available from ASMFC, contact info@asmfc.org)

Hata D, Hallerman E (2009) Evaluation of the coastal horseshoe crab trawl survey for estimating juvenile recruitment and mortality: Supplemental report to the Atlantic States Marine Fisheries Commission Horseshoe Crab Technical Committee. Virginia Polytechnic Institute and State University, Blacksburg, Virginia, USA (available from ASMFC, contact info@asmfc.org)

Hedgpeth J (1954) Gulf of México, its origin, waters, and marine life. Fish Bull Fish Wildl Serv 55(89):203-214

Herrera J, Álvarez C, Merino F, Aguilar A (2010) Mareas rojas en las costas de Yucatán. In: Durán R, Méndez M (eds) Biodiversidad y desarrollo humano en Yucatán. Springer, Mérida

Hummon WD, Fleecer JW, Hummon MR (1976) Meiofaunamacrofauna interactions. I. Sand beach meiofauna affected by maturing Limulus eggs. Chesap Sci 17:292-298

Hurton L, Berkson J (2006) Potential causes of mortality for horseshoe crabs (Limulus polyphemus) during the biomedical bleeding process. Fish Bull 104:293-298

Ives JE (1891) Crustacea from the northern coast of Yucatán, the harbor of Vera Cruz, the west coast of Florida and the Bermuda Islands. Proc Acad Nat Sci Phila 43:176-207

Jackson NL, Nordstrom KF (2009) Strategies to conserve and enhance sandy barrier habitat for horseshoe crabs. In:
Tanacredi JT, Botton ML, Smith DR (eds) Biology and conservation of horseshoe crabs. Springer, New York, pp 399-416

Jackson NL, Nordstrom KF, Eliot I, Masselink G (2002) "Low energy" sandy beaches in marine and estuarine environments: a review. Geomorphology 48:147-162

Jackson NL, Nordstrom KF, Smith DR (2005a) Influence of waves and horseshoe crab spawning on beach morphology and sediment characteristics on a sandy estuarine beach, Delaware Bay, New Jersey, USA. Sedimentology 52:1097-1108

Jackson NL, Smith DR, Nordstrom KF (2005b) Comparison of sediment characteristics on nourished and un-nourished estuarine beaches in Delaware Bay, New Jersey. Z Geomorphol Suppl 141:31-45

Jackson NL, Smith DR, Tiyarattanachi R, Nordstrom KF (2007) Evaluation of a small beach nourishment project to enhance habitat suitability for horseshoe crabs. Geomorphology 89:172-185

Jackson NL, Smith DR, Nordstrom KF (2008) Physical and chemical changes in the foreshore of an estuarine beach: implications for viability and development of horseshoe crab (Limulus polyphemus) eggs. Mar Ecol Prog Ser 355:209-218

Jackson NL, Nordstrom KF, Saini S, Smith DR (2010) Effects of nourishment on the form and function of an estuarine beach. Ecol Eng 36:1709-1718

Jackson NL, Nordstrom KF, Saini S, Smith DR (2015) Influence of configuration of bulkheads on use of estuarine beaches by horseshoe crabs and foraging shorebirds. Environ Earth Sci. doi:10.1007/s12665-015-4592-3

James-Pirri MJ, Tuxbury K, Marino S, Koch S (2005) Spawning densities, egg densities, size structure, and movement patterns of spawning horseshoe crabs Limulus polyphemus within four coastal embayments on Cape Cod, Massachusetts. Estuaries 28:296-313

James-Pirri MJ, Veillette PA, Leschen AS (2012) Selected hemolymph constituents of captive, biomedically bled, and wild caught adult female American horseshoe crabs (Limulus polyphemus). Mar Freshw Behav Physiol 45:281-289

Jegla T, Costlow J (1982) Temperature and salinity effects on developmental and early posthatch stages of Limulus. In: Bonaventura J, Bonaventura C, Tesh S (eds) Physiology and biology of horseshoe crabs. Alan R. Liss, New York, pp 103-113

Johnson SL, Brockmann HJ (2010) Costs of multiple mates: an experimental study in horseshoe crabs. Anim Behav 80:773-782

Kasinak J, Bartholomew K, Beekey MA, Mattei JH (2011) Movement patterns and population genetics of the American horseshoe crab in relation to Long Island Sound conservation strategies. In: Proceedings of the 2010 biennial long Island sound research conference. University of Connecticut, Stamford. http://lisfoundation.org/ downloads/lisrc_proceedings2010.pdf. Accessed 27 July 2016

Keinath JA (2003) Predation of horseshoe crabs by loggerhead sea turtles. In: Shuster CN Jr, Barlow RB, Brockmann HJ (eds) The American horseshoe crab. Harvard Press, Cambridge, pp 152-153 
Kin A, Błażejowski B (2014) The horseshoe crab of the genus Limulus: living fossil or stabilomorph? PLoS ONE 9(10):e108036. doi:10.1371/journal.pone.0108036

King TL, Eackles MS, Spidle AP, Brockmann HJ (2005) Regional differentiation and sex-biased dispersal among populations of the horseshoe crab Limulus polyphemus. Trans Am Fish Soc 134:441-465

King TL, Eackles MS, Aunins AW, Brockmann HJ, Hallerman E, Beaver BL (2015) Conservation genetics of the American horseshoe crab (Limulus polyphemus): allelic diversity, zones of genetic discontinuity, and regional differentiation. In: Carmichael RH, Botton ML, Shin PKS, Cheung SG (eds) Changing global perspectives on horseshoe crab biology, conservation and management. Springer, New York, pp 65-96

Kingsley JS (1901) Preliminary catalogue of the marine invertebrata of Casco Bay, Maine. Proc Portland Soc Nat Hist 2:159-183

Kraeuter JN, Fegley SR (1994) Vertical disturbance of sediments by horseshoe crabs (Limulus polyphemus) during their spawning season. Estuaries 17:288-294

Kreamer G, Michels S (2009) History of horseshoe crab harvest on Delaware Bay. In: Tanacredi JT, Botton ML, Smith DR (eds) Biology and conservation of horseshoe crabs. Springer, New York, pp 299-313

Kurz W, James-Pirri MJ (2002) The impact of biomedical bleeding on horseshoe crab, Limulus polyphemus, movement patterns on Cape Cod, Massachusetts. Mar Freshw Behav Physiol 35:261-268

Landau BJ, Jones DR, Zarnoch CB, Botton ML (2015) The use of aquaculture to enhance horseshoe crab populations: an example from Delaware Bay. In: Carmichael RH, Botton ML, Shin PKS, Cheung SG (eds) Changing global perspectives on horseshoe crab biology, conservation and management. Springer, New York, pp 513-536

Landi AA, Vokoun JC, Howell P, Auster P (2015) Predicting use of habitat patches by spawning horseshoe crabs (Limulus polyphemus) along a complex coastline with field surveys and geospatial analyses. Aquat Conserv 25:380-395

Laughlin R (1983) The effects of temperature and salinity on larval growth of the horseshoe crab Limulus polyphemus. Biol Bull 164:93-103

Laughlin RB Jr, Neff JM (1977) Interactive effects of temperature, salinity shock, and chronic exposure to no. 2 fuel oil on survival, development rate and respiration of the horseshoe crab Limulus polyphemus. In: Wolff DA (ed) Fate and effects of petroleum hydrocarbons in marine organisms and ecosystems. Pergammon Press, Oxford, pp 182-191

Leschen AS, Correia SJ (2010) Mortality in female horseshoe crabs (Limulus polyphemus) from biomedical bleeding and handling: implications for fisheries management. Mar Freshw Behav Physiol 43:135-147

Leschen AS, Grady SP, Valiela I (2006) Fecundity and spawning of the Atlantic horseshoe crab, Limulus polyphemus, in Pleasant Bay, Cape Cod, Massachusetts, USA. Mar Ecol 27:54-65

Levin J, Hochstein HD, Novitsky TJ (2003) Clotting cells and Limulus amebocyte lysate: an amazing analytical tool. In: Shuster CN Jr, Barlow RB, Brockmann HJ (eds) The
American horseshoe crab. Harvard University Press, Cambridge, pp 310-340

Lloyd WA (1874) On the occurrence of Limulus polyphemus off the coast of Holland, and on the transmission of aquarium animals. Zoologist 9(ser. 2):3845-3855

Loveland RE, Botton ML (1992) Size dimorphism and the mating system in horseshoe crabs Limulus polyphemus $\mathrm{L}$. Anim Behav 44:907-916

Loveland RE, Botton ML (2015) Sea level rise in Delaware Bay, USA: adaptations of spawning horseshoe crabs (Limulus polyphemus) to the glacial past, and the rapidly changing shoreline of the Bay. In: Carmichael RH, Botton ML, Shin PKS, Cheung SG (eds) Changing global perspectives on horseshoe crab biology, conservation and management. Springer, New York, pp 41-64

Loveland RE, Botton ML, Shuster CN Jr (1996) Life history of the American horseshoe crab (Limulus polyphemus L.) in Delaware Bay and its importance as a commercial resource. In: Farrell J, Martin C (eds) Proceedings of the horseshoe crab forum: status of the resource. University of Delaware Sea Grant College Program, Lewes, pp 15-22

MacGinitie GE, MacGinitie N (1949) Natural history of marine animals. McGraw-Hill, New York

Manly BFJ (2001) Statistics for environmental science and management. Chapman and Hall/CRC, Boca Raton

Mariño-Tapia I, Herrera-Silveira J, Enríquez-Ortiz C, MedellínMayoral G, González Leija M, Uc-Sánchez E, Medina Gómez I (2011) Estudios batimétricos, hidrodinámicos y de calidad de agua de lagunas costeras de Yucatán. Research Project Report. Centro de Investigación y Estudios Avanzados del Instituto Politécnico Nacional Unidad Mérida. México

Mattei JH, Beekey MA, Rudman A, Woronik A (2010) Reproductive behavior in horseshoe crabs: does density matter? Curr Zool 56:634-642

McGowan CP, Hines JE, Nichols JD, Lyons JE, Smith DR, Kalasz KS, Niles LJ, Dey AD, Clark NA, Atkinson PW, Minton CTD, Kendall W (2011a) Demographic consequences of migratory stopover: linking red knot survival to horseshoe crab spawning abundance. Ecosphere 2(6):art69

McGowan CP, Smith DR, Sweka JA, Martin J, Nichols JD (2011b) Multi-species modeling for adaptive management of horseshoe crabs and red knots in the Delaware Bay. Nat Resour Model 24:117-156

McGowan CP, Smith DR, Nichols JD, Lyons JE, Sweka JA, Kalasz K, Niles LJ, Wong R, Brust J, Davis M, Spear B (2015) Implementation of a framework for multi-species, multi-objective adaptive management in Delaware Bay. Biol Conserv 191:759-769

Michels SF (1996) Summary of trends in horseshoe crab abundance in Delaware. University of Delaware Sea Grant College Program, Lewes

Michels SF, Smith D, Bennett S (2008) Horseshoe crab spawning activity in Delaware Bay: 1999-2007: report to the Atlantic States Marine Fisheries Commission's Horseshoe Crab Technical Committee. Atlantic States Marine Fisheries Commission, Arlington

Mikkelsen T (1988) The secret in the blue blood. Science Press, Beijing

Millard MJ, Sweka JA, McGowan CP, Smith DR (2015) Assessment and management of North American 
horseshoe crab populations, with emphasis on a multispecies framework for Delaware Bay, USA populations. In: Carmichael RH, Botton ML, Shin PKS, Cheung SG (eds) Changing global perspectives on horseshoe crab biology, conservation and management. Springer, New York, pp 407-431

Moore S, Perrin S (2007) Seasonal movement and resource-use patterns of resident horseshoe crab (Limulus polyphemus) populations in a Maine, USA Estuary. Estuaries Coasts 30:1016-1026

Moritz C (1994) Defining 'evolutionary significant units' for conservation. Trends Ecol Evol 9:373-375

Nordstrom KF, Jackson NL, Smith DR, Weber RG (2006) Transport of horseshoe crab eggs by waves and swash on an estuarine beach: implications for foraging shorebirds. Estuar Coast Shelf Sci 70:438-448

Novitsky TJ (2015) Biomedical implications for managing the Limulus polyphemus harvest along the northeast coast of the United States. In: Carmichael RH, Botton ML, Shin PKS, Cheung SG (eds) Changing global perspectives on horseshoe crab biology, conservation and management. Springer, New York, pp 483-500

O'Connell CW, Grady SP, Leschen AS, Carmichael RH, Valiela I (2003) Stable isotopic assessment of site loyalty and relationships between size and trophic position of the Atlantic horseshoe crab, Limulus polyphemus, within Cape Cod estuaries. Biol Bull 205:254-255

Ortegón I, Rosado A, Arjona A, Aguilar A (2011) La marea roja en la costa norte de la península de Yucatán. Bioagrociencias 4:32-38

Palsbøll PJ, Berube M, Allendorf FW (2007) Identification of management units using population genetic data. Trends Ecol Evol 22:11-16

Penn D, Brockmann HJ (1994) Nest site selection in horseshoe crab, Limulus polyphemus. Biol Bull 187:373-384

Penn D, Brockmann HJ (1995) Age-based stranding and righting in male horseshoe crabs, Limulus polyphemus. Anim Behav 49:1531-1539

Pierce JC, Tan G, Gaffney PM (2000) Delaware Bay and Chesapeake Bay populations of the horseshoe crab Limulus polyphemus are genetically distinct. Estuaries 23:690-698

Provancha JA, Lowers R, Mota M, Holloway-Adkins K, Reyier E, Scheidt D (2006) Trials and tribulations of tracking sea turtles in mosquito lagoon-trends in abundance and results from the passive acoustic monitoring network. In: Frick M, Panagopoulou A, Rees AF, Williams K (eds) 26th Annual symposium on sea turtle biology and conservation, Island of Crete, Greece, 2006. International Sea Turtle Society, pp 315-316

Reid JP, Bonde RK (1990) Alligator mississippiensis (American alligator) diet. Herpetol Rev 21(3):59

Richmond EA (1962) The fauna and flora of Horn Island, Mississippi. Gulf Res Rep 1:59-106

Riska B (1981) Morphological variation in the horseshoe crab Limulus polyphemus. Evolution 35:647-658

Ropes JW (1961) Longevity of the horseshoe crab, Limulus polyphemus (L.). Trans Am Fish Soc 90:79-80

Rosales-Raya M (1999) Caracterización ambiental de sitios de anidación de Limulus polyphemus L. Estudio en Isla Aguada, Isla Pájaros, Cabrera e Icahao, Campeche, México
(1990-1992). Master's thesis. Facultad de Ciencias. Universidad Nacional Autónoma de México

Rosales-Raya M, de la Lanza Espino G, Gómez-Aguirre S (1997) Caracterización granulométrica de áreas de anidación de Limulus polyphemus (Merostomata) en el litoral de Campeche, México. In: Sánchez Zamora A, Amador Del Ángel LE (eds) Memorias del Congreso Regional de Ciencia y Tecnología de la Península de Yucatán, CONACYT-El Colegio de la Frontera Sur-Universidad Autónoma de Campeche, Campeche, México pp 183-185

Rudkin DM, Young GM (2009) Horseshoe crabs-an ancient ancestry revealed. In: Tanacredi JT, Botton ML, Smith DR (eds) Biology and conservation of horseshoe crabs. Springer, New York, pp 25-44

Rudloe AE (1979) Locomotor and light responses of larvae of the horseshoe crab Limulus polyphemus (L.). Biol Bull 157:494-505

Rudloe AE (1980) The breeding behavior and patterns of movement of horseshoe crabs Limulus polyphemus in the vicinity of breeding beaches in Apalachee Bay, Florida. Estuaries 3:177-183

Rudloe AE (1981) Aspects of the biology of juvenile horseshoe crabs Limulus polyphemus. Bull Mar Sci 31:125-133

Rudloe AE (1982) Man's influence as an environmental threat to Limulus. In: Bonaventura J, Bonventura C, Tesh S (eds) Physiology and biology of horseshoe crabs: studies on normal and environmentally stressed animals. Alan R. Liss, New York, pp 297-300

Rudloe AE (1983) The effect of heavy bleeding on mortality of the horseshoe crab, Limulus polyphemus, in the natural environment. J Invertebr Pathol 42:167-176

Rudloe AE (1985) Variation in the expression of lunar and tidal behavior rhythms in the horseshoe crab, Limulus polyphemus. Bull Mar Sci 36:388-395

Rutecki D, Carmichael R, Valiela I (2004) Magnitude of harvest of Atlantic horseshoe crabs, Limulus polyphemus, in Pleasant Bay, Massachusetts. Estuaries Coasts 27:179-187

Sandifer PA, Miglarese JV, Calder DR, Manzi JJ, Barclay LA (1980) Ecological characterization of the sea island coastal region of South Carolina and Georgia. Vol. III: biological features of the characterization area. US Fish and Wildlife Service, Office of Biological Services, Washington. US Fish and Wildlife Service/Office Biological Services, Washington. FWS/OBS-79/42

Sasson DA, Johnson SL, Brockmann HJ (2012) The role of age on sperm traits in the American horseshoe crab, Limulus polyphemus. Anim Behav 84:975-981

Saunders NC, Kessler LG, Avise JC (1986) Genetic variation and geographic differentiation in mitochondrial DNA of the horseshoe crab, Limulus polyphemus. Genetics 112:613-627

Schaller SY (2002) Horseshoe crab Limulus polyphemus spawning surveys in Maine, 2001. American fisheries society annual meeting. Baltimore, MD abstract \#24261566

Schaller SY (2011) Taunton Bay, Maine horseshoe crab tagging study 10th year report: preliminary findings. Maine Department of Marine Resources, W. Boothbay Harbor, Maine

Schaller S, Dorsey F (2011) Taunton Bay horseshoe crab tagging study: the 10 year report. Friends of Taunton Bay Newsletter No. 40. http://friendsoftauntonbay.org/wp- 
content/uploads/2011/07/Winter-20112.pdf. Accessed 3 Feb 2016

Schaller S, Thayer P, Hanson S, LaTulippe S, Solet E (2005) Maine horseshoe crab (Limulus polyphemus) spawning surveys, 2004. Casco Bay Estuary Partnership, Portland

Schaller SY, Chabot CC, Watson WH III (2010) Seasonal movements of American horseshoe crabs Limulus polyphemus in the Great Bay Estuary, New Hampshire (USA). Curr Zool 56:587-598

Scheidt D, Lowers R (2001) Using an aerial survey to document the extent of a horseshoe crab die-off in Florida. American Fisheries Society Annual Meeting, Baltimore

Secretaría de Comunicaciones y Transportes (2016) Manual de dimensionamiento portuario. http://www.sct.gob.mx/ fileadmin/CGPMM/PNDP2008/htm/nac.htm. Accessed 18 Jul 2016

SEDESOL (1994) NORMA Oficial Mexicana NOM-059ECOL-1994, que determina las especies y subespecies de flora y fauna silvestres terrestres y acuáticas en peligro de extinción, amenazadas, raras y las sujetas a protección especial, y que establece especificaciones para su protección. México City: SEDESOL (Issued May 5th 1994)

Sekiguchi K (1988) Biology of horseshoe crabs. Science House Co Ltd, Tokyo

Sekiguchi K, Yamamichi Y, Costlow JD (1982) Horseshoe crab developmental studies: normal embryonic development of Limulus polyphemus compared with Tachypleus tridentatus. In: Bonaventura J, Bonaventura C, Tesh S (eds) Physiology and biology of horseshoe crabs. Alan R. Liss, New York, pp 53-73

Selander RK, Yang SY, Lewontin RC, Johnson WE (1970) Genetic variation in the horseshoe crab (Limulus polyphe$m u s)$, a phylogenetic "relic". Evolution 24:402-414

SEMARNAT (2010) Norma Oficial Mexicana NOM-059SEMARNAT-2010, Protección ambiental-Especies nativas de México de flora y fauna silvestres-Categorías de riesgo y especificaciones para su inclusión, exclusión o cambio-Lista de especies en riesgo. SEMARNAT, Mexico City (issued Dec 30th 2010)

Seney EE (2007) Musick JA (2007) Historical diet analysis of loggerhead sea turtles (Caretta caretta) in Virginia. Copeia 2:478-489

Shuster CN Jr (1979) Distribution of the American horseshoe "crab", Limulus polyphemus (L.). In: Cohen E (ed) Biomedical applications of the horseshoe crab (Limulidae). Alan R. Liss, New York, pp 3-26

Shuster CN Jr (1982) A pictorial review of the natural history and ecology of the horseshoe crab Limulus polyphemus, with reference to other Limulidae. In: Bonaventura J, Bonaventura C, Tesh S (eds) Physiology and biology of horseshoe crabs. Alan R. Liss, New York, pp 1-52

Shuster CN Jr (2001) Two perspectives: horseshoe crabs during 420 million years, worldwide, and the past 150 years in the Delaware Bay area. In: Tanacredi JT (ed) Limulus in the limelight: a species 350 million years in the making and in peril?. Springer, New York, pp 17-40

Shuster CN Jr (2003) King crab fertilizer: a once-thriving Delaware Bay industry. In: Shuster CN Jr, Barlow RB, Brockmann HJ (eds) The American horseshoe crab. Harvard University Press, Cambridge, pp 341-357
Shuster CN Jr, Botton ML (1985) A contribution to the population biology of horseshoe crabs Limulus polyphemus in Delaware Bay. Estuaries 8:363-372

Shuster Jr CN (1950) Observations on the natural history of the American horseshoe crab, Limulus polyphemus. Woods Hole Oceanographic Institution Contribution Mo. 564, MA

Shuster Jr CN (1958) On morphometric and seriological relationships within the Limulidae, with particular reference to Limulus polyphemus (L.). Dissertation, New York Univiersity, Dissertation Abstracts, vol 18, pp 371-372

Shuster Jr CN (1985) Introductory remarks on the distribution and abundance of the horseshoe crab, Limulus polyphemus, spawning in the Chesapeake Bay area. In: The Chesapeake: prologue to the future. Proceedings of the Chesapeake Bay symposium, national marine educators conference, pp 34-38. Available from Marine Resources Library, Charleston, SC, USA

Shuster CN Jr, Sekiguchi K (2003) Growing up takes about ten years and eighteen stages. In: Shuster CN Jr, Barlow RB, Brockmann HJ (eds) The American horseshoe crab. Harvard University Press, Cambridge, pp 103-132

Shuster CN Jr, Sekiguchi K (2009) Basic habitat requirements of the extant species of horseshoe crabs (Limulacea). In: Tanacredi JT, Botton ML, Smith DR (eds) Biology and conservation of horseshoe crabs. Springer, New York, pp 115-129

Shuster CN Jr, Barlow RB, Brockmann HJ (2003) The American horseshoe crab. Harvard University Press, Cambridge

Silva-Casarín R, Villatoro Lacouture MM, Ramos Durón FJ, Pedroza Paez D, Ortiz Perez MA, Mendoza Baldwin EG, Delgadillo Calzadilla MA, Escudero Castillo MC, Féliz Delgado A, Cid Salinas A (2014) Caracterización de la zona costera y plantemaineto de elementos técnicos para la elaboración de criterios de regulación y manejo sustentable. Universidad Nacional Autónoma de MéxicoInstituto de Ingeniería, México

Smith MD, Brockmann HJ (2014) The evolution and maintenance of sexual size dimorphism in horseshoe crabs: an evaluation of six functional hypotheses. Anim Behav 96:127-139

Smith DR, Michels SF (2006) Seeing the elephant: importance of spatial and temporal coverage in a large-scale volunteerbased program to monitor horseshoe crabs. Fisheries 31:485-491

Smith DR, Pooler PS, Loveland RE, Botton ML, Michels SF, Weber RG, Carter DB (2002a) Horseshoe crab (Limulus polyphemus) reproductive activity on Delaware Bay beaches: interactions with beach characteristics. J Coast Res 18:730-740

Smith DR, Pooler PS, Swan BL, Michels S, Hall WR, Himchak P, Millard MJ (2002b) Spatial and temporal distribution of horseshoe crab (Limulus polyphemus) spawning in Delaware Bay: implications for monitoring. Estuaries 25:115-125

Smith DR, Millard MJ, Eyler S (2006) Abundance of adult horseshoe crabs (Limulus polyphemus) in Delaware Bay estimated from a bay-wide mark-recapture study. Fish Bull 104:456-464

Smith DR, Mandt MT, Macdonald PDM (2009a) Proximate causes of sexual size dimorphism in horseshoe crabs 
(Limulus polyphemus) of the Delaware Bay. J Shellfish Res 28:405-417

Smith DR, Millard MJ, Carmichael RH (2009b) Comparative status and assessment of Limulus polyphemus with emphasis on the New England and Delaware Bay populations. In: Tanacredi JT, Botton ML, Smith DR (eds) Biology and conservation of horseshoe crabs. Springer, New York, pp 361-386

Smith DR, Brousseau LJ, Mandt MT, Millard MJ (2010) Age and sex specific migration timing and frequency of horseshoe crab spawning in Delaware Bay: insights from a largescale radio telemetry array. Curr Zool 56:563-574

Smith DR, Jackson NL, Nordstrom KL, Weber RG (2011) Beach characteristics mitigate effects of onshore wind on horseshoe crab spawning: implications for matching with shorebird migration in Delaware Bay. Anim Conserv 14:575-584

Smith DR, McGowan CP, Daily JP, Nichols JD, Sweka JA, Lyons JE (2013) Evaluating a multi-species adaptive management framework: must uncertainty impede effective decision-making? J Appl Ecol 50:1431-1440

Southwell T (1873) King crab off the Dutch coast. The Zoologist 8(Series 2):3740

Sprandel GL, Gore JA, Cobb DT (1997) Winter shorebird survey final performance report. Florida Game and Fresh Water Fish Commission, Tallahassee

Steele P, Bert TM, Johnston KH, Levett S (2002) Efficiency of bycatch reduction devices in small otter trawls used in the Florida shrimp fishery. Fish Bull 100:338-350

Strobel CJ, Brenowitz AH (1981) Effects of Bunker C oil on juvenile horseshoe crabs (Limulus polyphemus). Estuaries 4:157-159

Swan BL (2005) Migrations of adult horseshoe crabs, Limulus polyphemus, in the middle Atlantic bight: a 17-year tagging study. Estuaries 28:28-40

Sweka JA, Smith DR, Millard MJ (2007) An age-structured population model for horseshoe crabs in the Delaware Bay area to assess harvest and egg availability for shorebirds. Estuaries Coasts 30:277-286

Sweka JA, Klopfer M, Millard MJ, Nesslage G, Olszewski S, Smith DR, Sysak R, Wong R (2013) Horseshoe crab stock assessment update. Atlantic States Marine Fisheries Commission, Arlington. http://www.asmfc.org/uploads/ file//52a88db82013HSC_StockAssessmentUpdate.pdf. Accessed 3 Feb 2016

Tanacredi JT (2001) Limulus in the limelight: a species 350 million years in the making and in peril?. Springer, New York

Tenorio-Fernandez L, Gonez-Valdez J, Mariño-Tapia I, Enriquez C, Valle-Levinson A, Parra SM (2015) Tidal dynamics in a frictionally dominated tropical lagoon. Cont Shelf Res 114:16-28

Thompson M (1998) Assessments of the population biology and critical habitat for the horseshoe crab, Limulus polyphemus, in the South Atlantic Bight. MS thesis, Medical University of South Carolina, University of Charleston

Towle DW, Henry RP (2003) Coping with environmental changes: physiological challenges. In: Shuster $\mathrm{CN}$ Jr, Barlow RB, Brockmann HJ (eds) The American horseshoe crab. Harvard University Press, Cambridge, pp 224-244
Tsuchiya K (2009) The history of horseshoe crab research and conservation in Japan. In: Tanacredi JT, Botton ML, Smith DR (eds) Biology and conservation of horseshoe crabs. Springer, New York, pp 559-570

Vasquez MC, Johnson SL, Brockmann HJ, Julian D (2015a) Nest site selection minimizes environmental stressor exposure in the American horseshoe crab, Limulus polyphemus. J Exp Mar Biol Ecol 463:105-114

Vasquez MC, Murillo A, Brockmann HJ, Julian D (2015b) Multiple-stressor interactions influence embryo development rate in the American horseshoe crab, Limulus polyphemus. J Exp Biol 218:2355-2364

Venosa AD, Suidan MT, Wrenn BA, Strohmeier KL, Haines JR, Eberhart BL, Holder E (1996) Bioremediation of an experimental oil spill on the shoreline of Delaware Bay. Environ Sci Technol 30:1764-1775

Wakefield K (2013) Saving the horseshoe crab: designing a more sustainable bait for regional eel and conch fisheries. Delaware Sea Grant Report. http://www.deseagrant.org/ sites/default/files/attachments/SavingTheHorseshoeCrab. pdf. Accessed 3 Feb 2016

Wakida-Kusunoki AT (2005) Análisis de la captura incidental en la pesquería ribereña del camarón de siete barbas Xiphopenaeus kroyeri en las costas de Campeche, México. Proc Gulf Caribb Fish Inst 56:583-591

Wallace GE (1999) Potential effects of a horseshoe crab fishery on migratory shorebirds in the state of Florida. Technical report, Bureau of Wildlife Diversity Conservation, Florida fish and Wildlife Conservation Commission, Panama City, Florida

Walls EA, Berkson J (2003) Effects of blood extraction on horseshoe crabs (Limulus polyphemus). Fish Bull 101:457459

Walls EA, Berkson J, Smith SA (2002) The horseshoe crab, Limulus polyphemus: 200 million years of existence, 100 years of study. Rev Fish Sci 10:39-73

Watson WH III, Chabot CC (2010) High resolution tracking of horseshoe crab Limulus polyphemus movements in an estuary with a fixed array ultrasonic telemetry. Curr Zool 56:599-610

Watson WH III, Schaller SY, Chabot CC (2009) The relationship between small- and large-scale movements of horseshoe crabs in the Great Bay estuary and Limulus behavior in the laboratory. In: Tanacredi JT, Botton ML, Smith DR (eds) Biology and conservation of horseshoe crabs. Springer, New York, pp 131-147

Watson WH, Johnson SK, Whitworth CD, Chabot CC (2016) Rhythms of locomotion and seasonal changes in activity expressed by horseshoe crabs in their natural habitat. Mar Ecol Prog Ser 542:109-121

Weber RG, Carter DB (2009) Distribution and development of Limulus egg clusters on intertidal beaches in Delaware Bay. In: Tanacredi JT, Botton ML, Smith DR (eds) Biology and conservation of horseshoe crabs. Springer, New York, pp 249-266

Wenner E, Thompson M (2000) Evaluation of harvesting impacts and population trends for Limulus polyphemus in South Carolina. South Carolina Department of Natural Resources, Marine Resources Research Institute. National Oceanic and Atmospheric Administration Final Report 
Widener JW, Barlow RB (1999) Decline of a horseshoe crab population on Cape Cod. Biol Bull 197:300-302

Witherington BE, Witherington D (2015) Our sea turtles: a practical guide for the Atlantic and Gulf, from Canada to Mexico. Pineapple Press, Sarasota

Wolff T (1977) The horseshoe crab (Limulus polyphemus) in North European waters. Vidensk Meddr Dansk Naturh Foren 140:39-52

Woodward-Clyde Consultants (1994) Biological resources of Indian River Lagoon. Indian River Lagoon National Estuary Program. No. 92F274C. Final technical report

Zaldívar-Rae J, Sapién-Silva RE, Rosales-Raya M, Brockmann HJ (2009) American horseshoe crabs, Limulus polyphemus, in México: open possibilities. In: Tanacredi JT, Botton ML, Smith DR (eds) Biology and conservation of horseshoe crabs. Springer, New York, pp 97-113

Zetina K, Moreno R, Domínguez R, Ríos V (2009) Co-manejo para el estudio de hábitats rocosos afectados por la marea roja en las costas de Yucatán, México. In: Proceedings of the 61st Gulf and Caribbean Fisheries Institute, vol 61, pp 283-286

\section{Sources of unpublished materials}

Applied Biology Inc., Ray L. Lyerly \& Associates (1980) Biological and environmental studies at the Florida Power \& Light Company Cape Canaveral Plant and the Orlando Utilities Commission Indian River Plant, Volume II, Part I: Biological studies. Applied Biology, Inc., Atlanta, GA and Ray L. Lyerly \& Assoc., Dunedin

Florida Fish and Wildlife Conservation Commission. Horseshoe crab spawning beach survey. http://myfwc.com/research/ saltwater/crustaceans/horseshoe-crabs/survey-response/ 